\title{
The phylum Vertebrata: a case for zoological recognition
}

\author{
Naoki Irie ${ }^{1,2^{*}}$ (D) Noriyuki Satoh ${ }^{3}$ and Shigeru Kuratani ${ }^{4}$
}

\begin{abstract}
The group Vertebrata is currently placed as a subphylum in the phylum Chordata, together with two other subphyla, Cephalochordata (lancelets) and Urochordata (ascidians). The past three decades, have seen extraordinary advances in zoological taxonomy and the time is now ripe for reassessing whether the subphylum position is truly appropriate for vertebrates, particularly in light of recent advances in molecular phylogeny, comparative genomics, and evolutionary developmental biology. Four lines of current research are discussed here. First, molecular phylogeny has demonstrated that Deuterostomia comprises Ambulacraria (Echinodermata and Hemichordata) and Chordata (Cephalochordata, Urochordata, and Vertebrata), each clade being recognized as a mutually comparable phylum. Second, comparative genomic studies show that vertebrates alone have experienced two rounds of whole-genome duplication, which makes the composition of their gene family unique. Third, comparative gene-expression profiling of vertebrate embryos favors an hourglass pattern of development, the most conserved stage of which is recognized as a phylotypic period characterized by the establishment of a body plan definitively associated with a phylum. This mid-embryonic conservation is supported robustly in vertebrates, but only weakly in chordates. Fourth, certain complex patterns of body plan formation (especially of the head, pharynx, and somites) are recognized throughout the vertebrates, but not in any other animal groups. For these reasons, we suggest that it is more appropriate to recognize vertebrates as an independent phylum, not as a subphylum of the phylum Chordata.
\end{abstract}

Keywords: Gene family, Gene expression profile, Molecular phylogeny, Organ development, Phylum Vertebrata, Zoological classification

\section{Background}

The origin and evolution of vertebrates has long been a focus of zoological study [1]. Vertebrates were distinguished from invertebrates as early as a few hundred years BC [2]. The present zoological taxonomy classifies Vertebrata as a subphylum of the phylum Chordata, together with two other invertebrate subphyla, Cephalochordata (lancelets) and Urochordata (ascidians). The aim of this review is to discuss whether the subphylum Vertebrata is supported by data obtained from recent zoological research.

The present classifications of vertebrates was established by Balfour [3] in 1880-1881(Fig. 1a), and the subphylum rank of Vertebrata has not been the subject of critical discussion since that time. Prior to Balfour's

\footnotetext{
* Correspondence: irie@bs.s.u-tokyo.ac.jp

${ }^{1}$ Department of Biological Sciences, School of Science, University of Tokyo, Tokyo 113-0033, Japan

${ }^{2}$ Universal Biology Institute, University of Tokyo, Tokyo 113-0033, Japan Full list of author information is available at the end of the article
}

classification, in the mid-to-late eighteenth century, lancelets [4] and tunicates [5] were considered invertebrates and grouped with Mollusca, although Yarrell [4] noted that lancelets possess a primitive axial rod and thus show some affinity to vertebrates. In 1794, Lamarck [6] proposed the phylum Vertebrata, distinguishing them from invertebrates (Fig. 1a). The publication of Charles Darwin's book On the origin of species in 1859 [7] led to vigorous discussion of animal evolution, including the classification of vertebrates. In 1866, Haeckel [8], himself a committed Darwinian, proposed a new concept for phylum Vertebrata, as comprising two subphyletic groups: vertebrates as Craniata (animals with heads) and lancelets as Acrania (animals without heads) (Fig. 1a).

In1886 and 1887, Kowalevsky reported his discovery of the notochord in ascidian larvae [9] and in lancelet adults [10]. His reports impressed zoologists with the affinity of these two invertebrates with vertebrates, as all three groups have a notochord. Following further discussion, in

(c) The Author(s). 2018 Open Access This article is distributed under the terms of the Creative Commons Attribution 4.0 International License (http://creativecommons.org/licenses/by/4.0/), which permits unrestricted use, distribution, and 


\section{a Key reports that led to the concept of the phylum Chordata}

\begin{tabular}{llll}
\hline & Vertebrates & Cephalochordates & Tunicates (Urochordates) \\
\hline Lamarck JB (1794) ${ }^{[6]}$ & Vertebrata & Mollusca & Mollusca \\
\hline Haeckel E (1866) ${ }^{[8]}$ & $\begin{array}{l}\text { Vertebrata } \\
\text { Craniata }\end{array}$ & $\begin{array}{l}\text { Vertebrata } \\
\text { Acrania }\end{array}$ & $\begin{array}{l}\text { Mollusca } \\
\text { (Tunicata) }\end{array}$ \\
\hline Lankester ER $(1877)^{[11]}$ & Vertebrata & Vertebrata & Vertebrata \\
& Craniata & Cephalochordata & Urochordata \\
\hline Balfour FM $(1880,1881)^{[3]}$ & Chordata & Chordata & Chordata \\
& Vertebrata & Cephalochordata & Urochordata \\
\hline This review & Vertebrata & Cephalochordata & Urochordata \\
\hline
\end{tabular}

\section{b a traditional view}

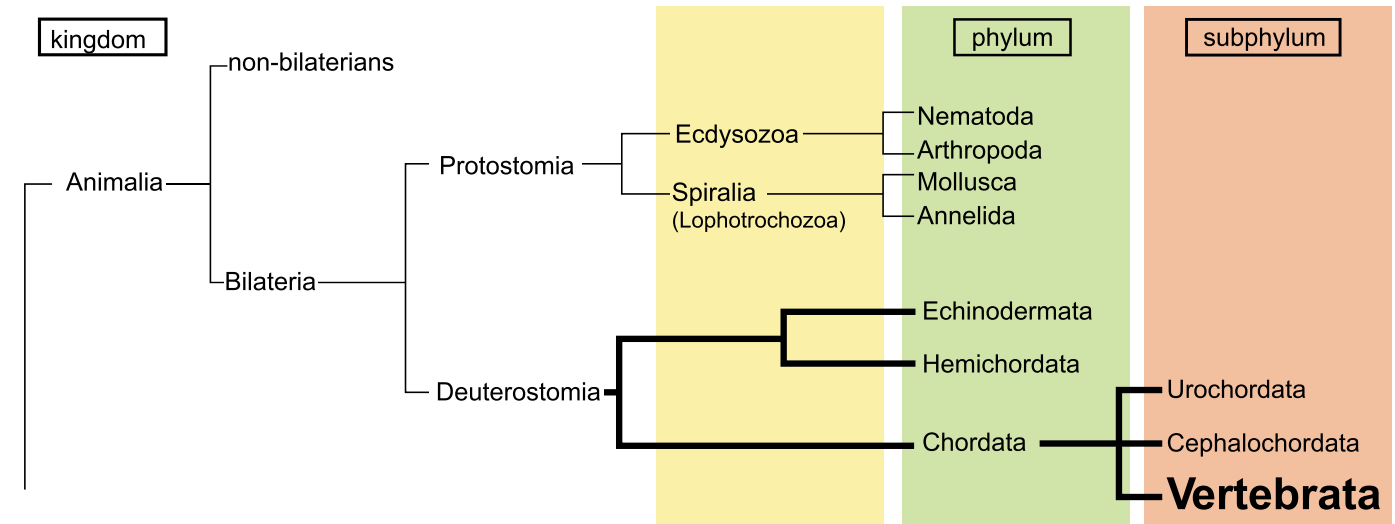

\section{C a proposed view}

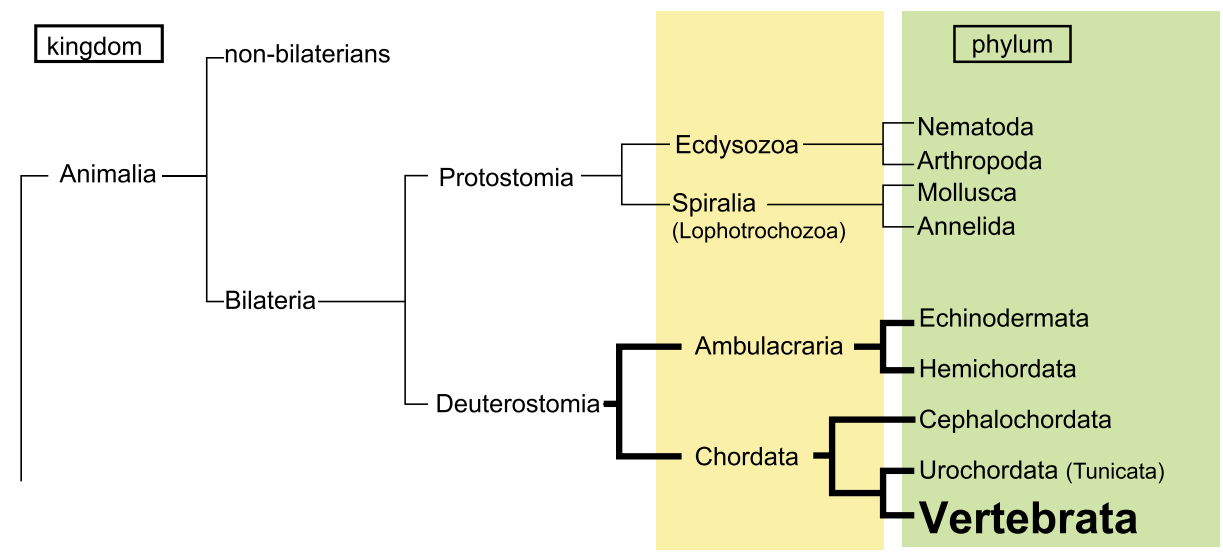

Fig. 1 (See legend on next page.) 
(See figure on previous page.)

Fig. 1 Subphylum Vertebrata of the phylum Chordata. a Key reports that led to the concept of the phylum Chordata. Terms in red are of phylum rank and those in black are of subphylum rank. Those in green were recognized as invertebrates at the times indicated in the first column. $\mathbf{b}$ Traditional view (upper) and c our proposed view (lower) of chordate phylogeny with respect to inter-phylum relationships. The proposed phylogeny regards the Cephalochordata, the Urochordata, and the Vertebrata as separate phyla, rather than as subphyla. (modified from [17])

1877, Lankester [11] proposed that the phylum Vertebrata consisted of three subphyla: Craniata, Cephalochordata (animals with a notochord that runs through the entire body to the tip of trunk), and Urochordata (or Tunicata, animals with a notochord that is present only in the tail) (Fig. 1a). Thus, the basic schema for the taxonomic classification of vertebrates and other notochordal taxa was fixed under Lankester's proposed system. The following year, Balfour [3] altered the terminology of Vertebrata to Chordata and Craniata to Vertebrata (Fig. 1a), further emphasizing the notochord (and the dorsal nerve cord or neural tube); this led to the current concept of the subphylum Vertebrata in the phylum Chordata.

Over the past three decades, extraordinary advances have been made in zoological classification thanks to the incorporation of new methods and technologies, including evolutionary developmental biology (evo-devo), molecular phylogeny, and comparative genomics. Our understanding of the phylogenic position of metazoan taxa or the evolutionary relationships among bilaterian groups is now changing as a result of data obtained using these new tools. For example, protostomes are now subdivided into two major groups-lophotrochozoans (spiralians) and ecdysozoans-on the basis of their molecular phylogeny (Fig. 1b) $[12,13]$. Nevertheless, the classification of the phylum Chordata and its three sub-phylum system has largely remained unchallenged, although recently a few researchers have come to question this taxonomy. For example, Swalla et al. [14] and Zeng and Swalla [15], on the basis of molecular phylogeny as determined by $18 \mathrm{~S}$ rDNA sequence comparison, suggested that tunicates are monophyletic and should therefore be recognized as a phylum. Satoh et al. [16] proposed a three-phylum system of chordates instead of the three-subphylum system. Although this notion was viewed with interest by many zoologists, and a growing body of research provides support for this viewpoint, the proposed phyletic status of Vertebrata has yet to gain widespread acceptance [17].. We review the results of recent studies in the molecular phylogeny of metazoans, comparative analysis of gene families, vertebrate-specific phylotypic stage, and body plan formation specific to vertebrates, and suggest that, based on this body of evidence, it is time for the zoological community to revisit the classification of the vertebrates.

\section{Molecular phylogeny}

The introduction of molecular phylogeny and its application to metazoans first occured in the 1980s. The initial use of molecular phylogeny was delayed in metazoans compared with other organisms such as prokaryotes, fungi, and plants, because metazoan phylogeny had been discussed in terms of the distinct characteristic features of each taxon, including fossil records, modes of embryogenesis, and larval and adult morphology. These basic methodological approaches to metazoan classification were well-established and had a long history of providing valid insights, and thus appeared too robust to be reevaluated using other methods. However, it was soon recognized that molecular phylogeny is a very useful method for inferring relationships between metazoan taxa at the family and order levels. Nevertheless, there are a number of issues regarding the phylogenetic position of metazoan taxa at the phylum level remain, including the nature of the ctenophore ancestor of all metazoans [13, 18, 19] and the association of Xenoturbella with the deuterostome ancestor [20]. (The latter issue is not discussed here, as we do not consider this animal group to fall within the scope of mainstream deuterostome evolution.) Many molecular phylogenic reports have tackled the classification or taxonomy of metazoans. We discuss three examples below.

The first example is the seminal report of two major clades of protostomes: Lophotrochozoa (platyhelminths/ annelids/mollusks) and Ecdysozoa (arthropods/nematodes) [13]. Protostomes are the largest group of bilaterians. The traditional view of protostome phylogeny emphasized the grade of complexity of the body plan; especially the development of the body cavity or coelom [21]. Protostomes were subdivided on the basis of the mode of body cavity formation into acoelomates (with no distinct body cavity) such as platyhelminths; pseudocoelomates (with a poorly developed body cavity) such as nematodes; and coelomates (with a distinct body cavity) such as annelids, mollusks, and arthropods. An important argument was therefore whether the presence of a metameric body plan or trochophore-like larvae was critical for the classification of eucoelomic annelids, mollusks, and arthropods. The former provided a close relationship between annelids and arthropods, whereas the latter supported the intimate relationship between annelids and mollusks. Both the report by Aguinaldo et al. [12] and that of Halanych et al. [22] influenced many zoologists. Although several later researchers (e.g., [23]) 
have suggested that the clade "Lophotrochozoa" should be renamed "Spiralia," the Lophotrochozoa/Ecdysozoa classification has gradually gained acceptance. Recent comparative genomic studies suggest that ecdysozoans (arthropod-nematode clade) are a unique bilaterian group with gene families different from those of other groups, including diploblasts. (See section 2.)

The second example of the application of molecular phylogeny is the rearrangement of animal groups in relation to the phylum Annelida. Traditionally, Annelida was comprised of two major groups: Clitellata (earthworms and leeches) and Polychaeta (bristle worms). On the other hand, Sipuncula (peanut worms), Echiura (spoon worms), and Siboglinidae or Pogonophora (beard worms) were each recognized as independent phyla [24]. Recent molecular phylogeny suggests that these three taxa are also included in the larger taxon or phylum Annelida $[13,25]$. Although the positions of some sub-taxa remain uncertain, this scheme has gradually been accepted in the context of a robust evolutionary history of annelids and related bilaterians. In this system, either the peanut worms and spoon worms lost body segmentation during their evolution, or the annelids obtained their segmentation pattern independently.

The third example is the taxonomic expansion of reptiles among vertebrates. Traditionally, Gnathostomata comprises six classes-Chondrichthyes, Osteichthyes, Amphibia, Reptilia, Aves, and Mammalia-although it has been suggested that Aves (birds) branched off from the reptile lineage Archaeopteryx. Recent decoding of the genomes of reptiles [26] and birds [27], as well as molecular phylogenetic analysis [28], has clearly shown that the bird clade is incorporated among different clades of reptiles. In other words, Aves is now recognized as a lineage leading to a specific group within a complex set of reptiles.

Returning to the question of the phylogenetic relationship of deuterostome taxa, what has molecular phylogeny told us of the phylogenic positions of chordates and vertebrates? An early phase of deuterostome molecular phylogeny showed a grouping of echinoderms and hemichordates $[29,30]$; these are named "Ambulacraria," as originally proposed by Metchnikoff [31]. However, these studies failed to give a clear resolution of Ambulacraria/Chordata relationship due to the problem of long branch attraction caused by the fast substitution rate of urochordate sequences in the construction of molecular phylogeny trees.

In 2006, Delsuc et al. [32] performed an analysis that incorporated orthologous amino acid sequences of appendicularians and cephalochordates and demonstrated that, within the chordate clade, cephalochordates diverged first, and urochordates and vertebrates formed a sister group, as "Olfactores" (Fig. 1c) This relationship has been supported by further analyses that include different taxa and larger quantities of higher-quality molecular data [33, 34]. Debates on the evolutionary scenarios of sedimentary and free-living ancestors are now likely resolved: Chordate ancestors were free-living, like lancelets [17]. Figure 2 is a molecular phylogenetic diagram that pays particular attention to deuterostome relationships [35]. The tree was constructed by comparing the positions of 500,000 amino acids of 1565 families with single-copy orthologs present in 53 metazoan species with 30 sequenced genomes; presence-absence characters for introns and coding indels were also incorporated. This and other previous molecular phylogenetic studies have unambiguously demonstrated (1) the division of deuterostomes into two major groups-ambulacrarians and chordates; and (2) the divergence of cephalochordates first among the chordate lineages. On the basis of a relaxed molecular clock that incorporates data from fossil records and rates of amino acid substitution, the divergence time of deuterostomes and protostomes was estimated to be $\sim 670$ Mya; that of ambulacrarians and chordates $\sim 660$ Mya; that of echinoderms and hemichordates among the ambulacrarians was $\sim 600 \mathrm{Mya}$, and that of the three chordate groups $\sim 650$ Mya [35]. It is thus likely that chordates diverged earlier than, or at least at a similar time to, ambulacrarians. If we accept $t$ that Echinodermata and Hemichordata are two phyla of the higher clade Ambulacraria, then it might also be accepted that Chordata is another higher clade that comprises three phyla: Cephalochordata, Urochordata, and Vertebrata. In other words, Vertebrata may be more correctly described as a phylum, not a subphylum of the phylum Chordata.

\section{Whole-genome duplication and gene-family expansion}

Vertebrates experienced a two-round whole-genome duplication (2R-WGD) during their evolution. The vertebrate-specific $2 \mathrm{R}-\mathrm{WGD}$ has been supported by a great variety of evidence, including the existence of the Hox cluster, as discussed below. Whole-genome duplication also occurred in some ecdysozoan species, including the Atlantic horseshoe crab [36], house spider [37], and hexapods [38]. In general, WGD has been considered a major force of genome evolution that promotes animal diversity. However, it has been pointed out that WGD in these arthropods did not always lead to developmental and morphological diversity within groups. In contrast, vertebrate WGD may cause a supra-ordinal expansion of gene families, which is highly likely to represent the evolutionary force behind the complexity and diversity of vertebrate body plans. (See sections 3 and 4.) 


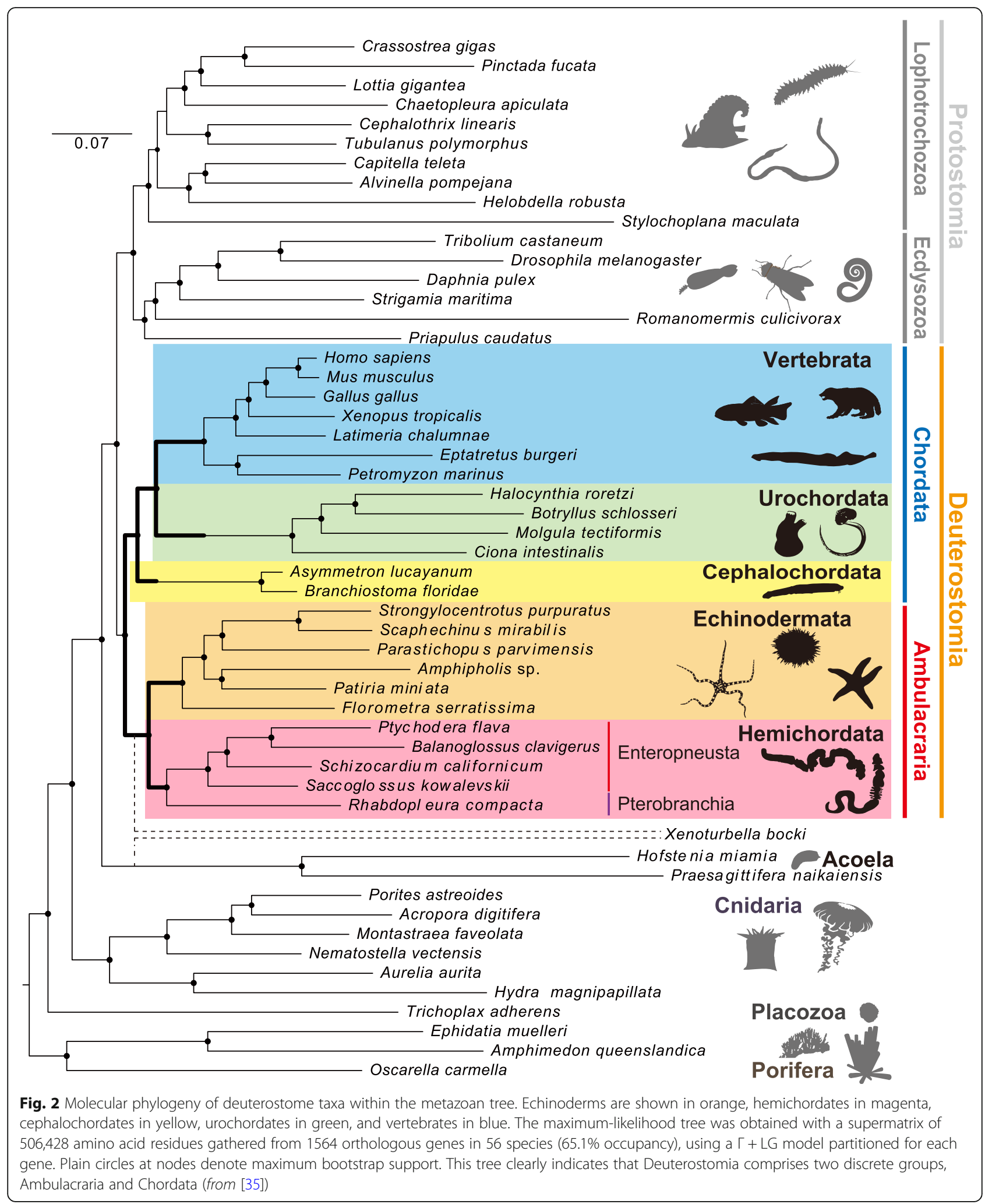

\section{Hox clusters}

Vertebrate-specific 2R-WGD has been exemplified by various genes and gene families, of which the Hox cluster is the best-known example. In most groups of protostomes and deuterostomes studied at high taxonomic levels to date, Hox genes (encoding 
homeodomain-containing transcription factors) are clustered in the same genomic region, known as the Hox cluster. The Hox cluster shows spatial and temporal collinearity. That is, the expression patterns of Hox genes reflect their positions in the cluster. Genes at the 3' end are expressed in, and pattern, the anterior end of the embryo, whereas genes at the $5^{\prime}$ end pattern the more posterior body parts (spatial collinearity). Moreover, gene position in the cluster also determines the time of onset of expression, with 3 '-end genes expressed in earlier developmental stages than those at the $5^{\prime}$ end (temporal collinearity). As a result, Hox genes are eventually expressed in a nested manner along the anterior-posterior axis of the animal body, resulting in a Hox code that bestows differential structural identity. (See section 4.)

Recent studies have revealed the organization of deuterostome Hox clusters- especially in echinoderms and hemichordates-and have thus shed more light on vertebrate-specific duplication of the Hox cluster in deuterostome taxa with shared common ancestors. Below, we discuss recent studies of the Hox cluster in cephalochordates, hemichordates, echinoderms, urochordates, and vertebrates.

The Hox cluster of cephalochordates has been studied extensively, as this taxon represents a key phylogenetic position for deducing the ancestral condition of chordates, and is a valuable out-group for evolutionary studies of vertebrates [39]. Cephalochordates possess the most prototypical Hox cluster identified so far in deuterostomes: the Floridian amphioxus Branchiostoma floridae contains a typical 13 genes, including three anterior (Hox1 to 3), six middle (Hox4 to 10), and three posterior (Hox11 to 13) genes (Fig. 3). The cluster also contains Hox 14 and 15, which represents the largest gene content for a Hox cluster hitherto reported, spanning a genomic stretch of $\sim 470 \mathrm{~kb}$, all in the same transcriptional orientation. The cluster has not suffered any rearrangements since the cephalochordates split from their chordate ancestor. However, discussion continues as to whether Hox 14 is shared by basal groups of vertebrates, and whether Hox15 is a true member of the cluster $[40,41]$.

Among ambulacrarians, hemichordates are thought to retain more features of the last common ancestor than echinoderms [17, 42]. A recent study identified the presence of a single Hox cluster in the genomes of two enteropneusts (acorn worms), Saccoglossus kowalevskii and Ptychodera flava (Fig. 3) [43]. The hemichordate Hox cluster reflects a prototypical organization among deuterostomes, showing an organization with 12 Hox genes arrayed in $\sim 500 \mathrm{~kb}$, all with the same transcriptional orientation, except for the terminal pair of ambulacrarian-specific posterior Hox genes, $A m b P b$ and $A m b P c$ (previously named Hox $11 / 13 b$ and Hox11/13c, respectively [43] (Fig. 3). The conservation of echinoderm Hox clusters has also been disclosed recently. The Hox cluster of the sea urchin, Strongylocentrotus purpuratus, is a single cluster of about $600 \mathrm{~kb}$ that contains 11 Hox genes (Hox4 is missing) [44] (Fig. 3). It also appears to have undergone re-ordering, as Hox $1-3$ are located near the posterior end of the cluster (Fig. 3). In addition, sea urchin Hox genes are expressed not during embryogenesis but during juvenile development. These data suggest that this Hox shuffling is associated with echinoderm-specific pentameric symmetry, although the function of these rearranged genes remains to be elucidated. However, the crown-of-thorns starfish, Acanthaster planci, has an organized Hox cluster of 11 genes, in which Hox6 is missing (Fig. 3) [45]. Because this starfish with pentameric symmetry retains an organized Hox cluster, the relationship between the echinoderm Hox rearrangement and pentameric symmetry requires further investigation.

As discussed above, Hox genes are conserved in well-organized clusters in both ambulacrarians and cephalochordates. The urochordates, however, represent an interesting exception. Urochordate genomes are highly divergent. For example, Ciona intestinalis possesses an atypically organized set of Hox genes [46-48]. The Hox cluster is divided into two groups located on different chromosomes [49]: Hox 1 to 6 and 10 on chromosome 1 and Hox 12 and 13 on chromosome 7 (Fig. 3). In addition, Hox 7 to 9 and 11 are absent in all ascidians sequenced so far. Nevertheless, collinearity seems somehow to have been retained in the Ciona Hox cluster [47].

In contrast to the single Hox cluster of invertebrate deuterostomes, jawed vertebrates contain four Hox clusters; because of 2R-WGD, the Hox clusters of vertebrates have increased to four paralogous groups, HoxA to HoxD (Fig. 3). If the Hox cluster of the last common ancestor consisted of 12 or 13 genes, 2R-WGD would imply the presence of 48 or 52 homeobox genes in vertebrates. In all such events, however, duplication of the Hox cluster was followed by the loss of various Hox gene, resulting in unique combinations of Hox genes in different groups, which can serve an identifying function akin to that of bar codes (a "genomic Hox-bar code") [50]. Comparison of the Hox inventories of different tetrapods has shown that there was a tetrapod ancestral condition of up to 41 Hox genes [51] and an amniote ancestral condition of 40 Hox genes (after the loss of Hox $(1)$, the full set of which is retained only by the green anole (Anolis carolinensis). Mammals and chickens have lost $\mathrm{HoxC} 3$ independently. Although the western clawed frog (Xenopus tropicalis) has 38 Hox genes, the 


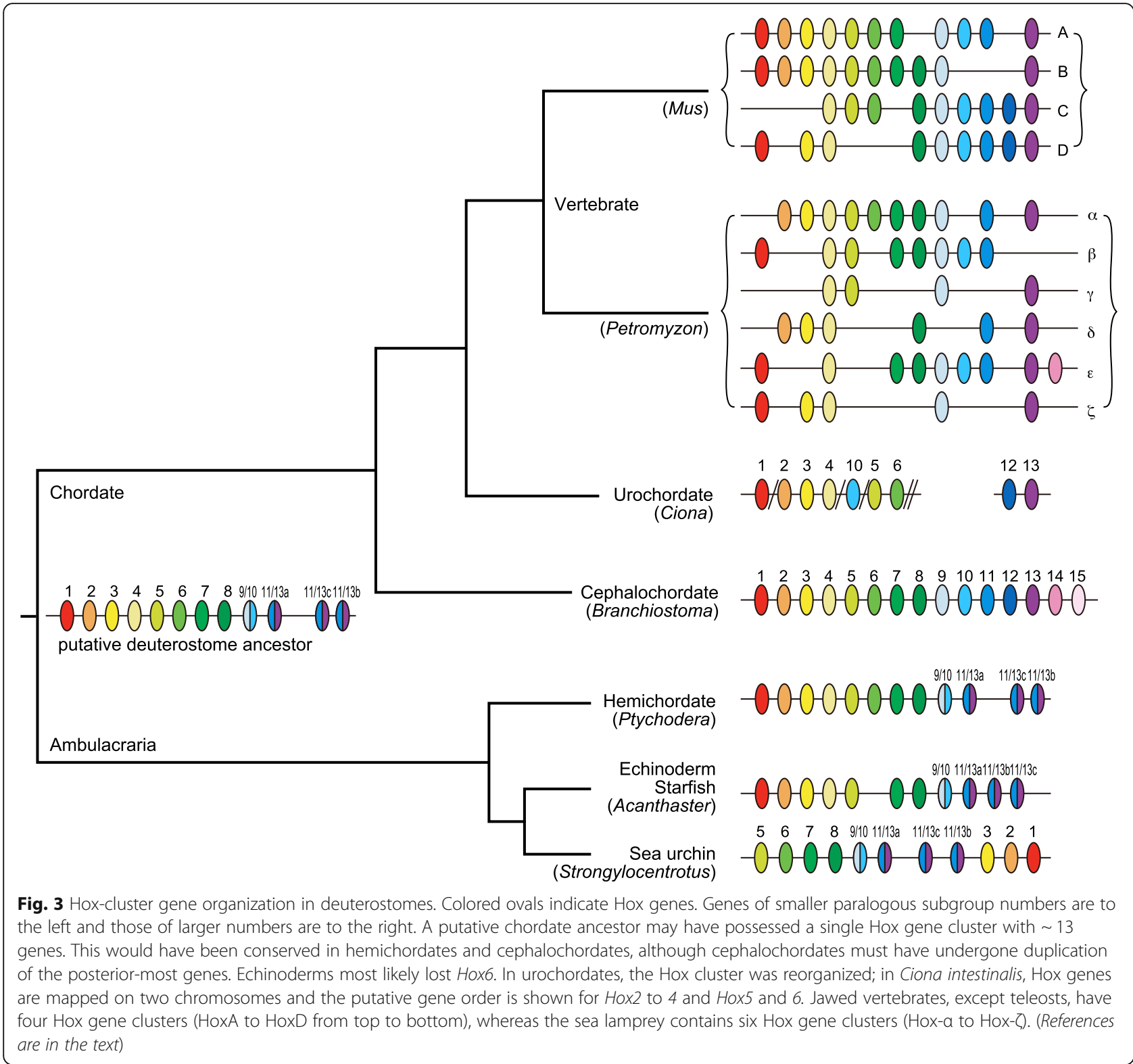

amphibian ancestor probably had 40 genes, after losing HoxD12.

Recent studies of Hox clusters in vertebrates have revealed more complex histories of WGD in vertebrates. First, the two main groups of gnathostomes are the chondrichthyans (cartilaginous fishes) and the osteichthyans (bony fishes). In contrast to the apparently complete loss of the HoxC cluster in elasmobranchs [52], teleosts are likely to have experienced an additional round of duplication (third WGD); the Atlantic salmon, Salmo salar, and the rainbow trout, Oncorhynchus mykiss, have 13 Hox clusters, arising from a salmonid-specific fourth round of WGD [52]. Salmo has 118 Hox genes plus eight pseudogenes [53] - the largest Hox repertoire reported to date.
The organization of the Hox cluster has been examined in cyclostomes (agnathans, or jawless vertebrates), yielding interesting results that shed light on the question of when the first and second round of WGD occurred. Cyclostomes are composed of two different groups, lampreys and hagfishes. In the case of the hagfish, Stadler et al. [54], using degenerate PCR, reported the presence of up to 33 Hox genes-fewer than expected-and Pascual-Anaya et al. [55] showed the conservation of temporal collinearity, as seen in jawed vertebrates. On the other hand, the sea lamprey Petromyzon marinus exhibits a unique phenomenon known as programmed genome rearrangement, in which, during embryogenesis, some portions of the genome are abbreviated such that the somatic cells retain only a 
portion of the genome originally retained in germ cells [56]. Recent decoding of the Petromyzon germ-cell genome by Smith et al. [57] revealed the presence of six Hox clusters in the genome (Hox- $\alpha$, Hox $-\beta$, Hox $-\gamma$, Hox $-\delta$, Hox- $\varepsilon$, and Hox- $\zeta$ ) (Fig. 3). Smith et al. discussed the important role of chromosomal-level duplication and the duplication of large-scale genomic regions in the establishment of Hox clusters on different chromosomes. It is therefore now highly likely that 2R-WGD occurred in the ancestor(s) of all vertebrate groups. This likelihood offers support for vertebrates as a discrete animal taxon that is distinct from any of the notochordal invertebrate taxa.

\section{(b) Expansion of gene families}

Vertebrates are characterized by various morphological, developmental, and physiological features. (See sections 3 and 4.) These include the neural crest and placodes that are involved in the formation of "new head" structures [58]; a complex central nervous system; jaws including pharyngeal gill structures; bone; an adaptive immune system; and a hormonal system associated with the hypothalamus, pituitary, and gonad [59]. Here, we do not discuss the evolution of these features; it seems reasonable that their evolution occurred through the expansion or diversification (or both) of gene families as a result of 2R-WGD. Recent decoding of the genomes of various animal groups has made it possible to compare gene family compositions among deuterostomes as well as protostomes and diploblasts. Custom clustering analysis revealing the numbers of gene families shared by deuterostomes (8716), ambulacrarians (9892), and chordates (9957) implies the presence of at least 8716 families of homologous genes in the deuterostome ancestor [35]. Analyses of these gene families have demonstrated the remarkable complexity of the vertebrate gene family (Fig. 4); this provides further evidence for vertebrates as a distinct and independent animal taxon.

So far at least three genome-decoding studies have analyzed the evolutionary changes in the content of gene families in metazoans $[35,60,61]$. The first analysis included the genomes of three lophotrochozoan species (one mollusk and two annelids) [60]; the second, two hemichordates [35]; and the third, nemertean, phoronid, and brachiopod genomes [61]. Figure 4a and b illustrate the work of Simakov et al. [60] and Luo et al. [61], respectively. Although different numbers of metazoan species are included, both results clearly indicate the independent and discrete clustering of vertebrate species (solid circles) from invertebrate species (dashed circles). This suggests that vertebrates differ distinctly from invertebrates in the constituents of gene families. These analyses show the affinity of deuterostomes and spiralians (dashed circles). Ecdysozoans, in contrast, were clustered or scattered apart from other metazoans (Fig. 4a and b), suggesting the specificity of this protostome group.

Additional hierarchical clustering analysis of gene families shared exclusively among metazoans clearly indicates a vertebrate-specific cluster (top-left corner of Fig. 4c, enclosed by yellow box) [61]. This figure also shows (1) clustering of the gene repertoire in deuterostomes (gapped by tunicates; upper right); (2) spiralian species (lower right) with affinity to cnidarians; and (3) an ecdysozoan-specific cluster (middle), suggesting that ecdysozoans diversified independently of other metazoans. In summary, as indicated by recent studies of molecular phylogeny and comparative genomics, vertebrates are unique among bilaterians and distinct from invertebrates. Taking these findings into consideration, it is evident that the prospective phylum Vertebrata is the first clearly classifiable animal phylum.

\section{Vertebrate-specific phylotypic period}

An animal phylum is generally defined as a monophyletic group of animals that share the same body plan (a set of basic anatomical features shared by animals of a certain lineage). A key problem in defining phyla thus lies in the difficulty in identifying distinct body plans among different animal groups; the situation becomes even more challenging when extinct species are taken into consideration [62]. In this sense, defining phyla is analogous to finding boundaries between continuous mountains, and this is the logic we have followed so far in the previous sections. Given that the boundaries should now be settled between, for example, hemichordates and echinoderms, it should now also be possible to settle on the other, comparable, boundaries between the three major chordate groups. In addition to the discussion above, another potential support for "phylum Vertebrata" has recently been suggested by the results of a comparative transcriptomic study of chordate embryos [63].

The study tested the phylotype hypothesis of the developmental hourglass model [64] by using chordate species [63]. According to the developmental hourglass model, the mid-embryonic, organogenesis period is the phase that is most conserved through embryogenesis (Fig. 5), and this phylotypic period defines the body plan for each animal phylum (phylotype hypothesis, [64-66]. Although recent transcriptomic studies have supported the presence of hourglass-like, mid-embryonic conservation patterns in a variety of animal groups, including vertebrates [67-71], Drosophila species [72], Caenorhabditis species [73, 74] and mollusks [75], the range of species compared was much narrower than at the phylum level, and it remains unclear whether the hourglass 
a

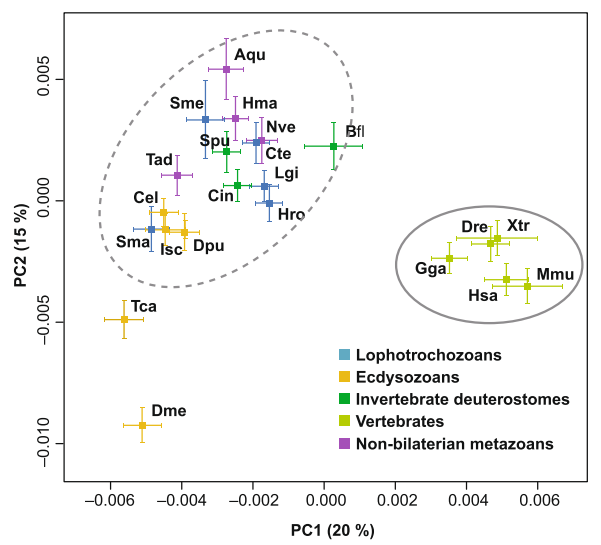

Aqu: Amphimedon queenslandica (demosponge) Bfl: Branchiostoma floridae (amphioxus) Cel: Caenorhabditis elegans Cin: Ciona intestinalis (sea squirt) Cte: Capitella teleta (polychaete) Dme: Drosophila melanogaster Dpu: Daphnia pulex (water flea) b

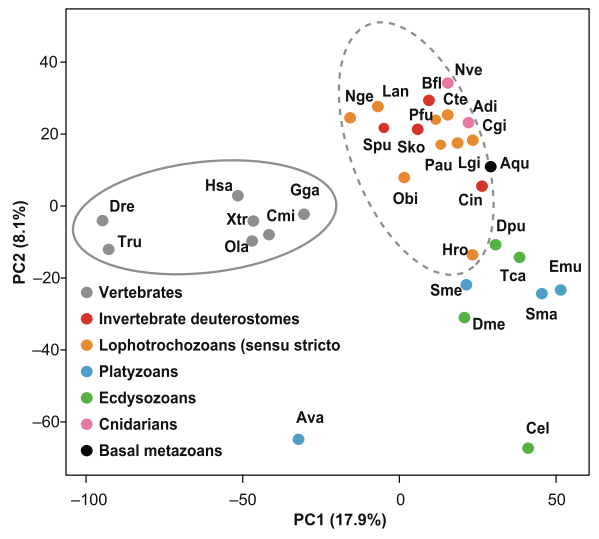

Nve: Nematostella vectensis (sea anemone) osoma mansoni (blood fluke) Sme: Schmidtea mediterranea (planarian) Spu: Strongylocentrotus purpuratus (sea urchin) Tad: Trichoplax adhaerens (placozoan) Tca: Tribolium castaneum (flour beetle) Xtr: Xenopus tropicalis (western clawed frog)

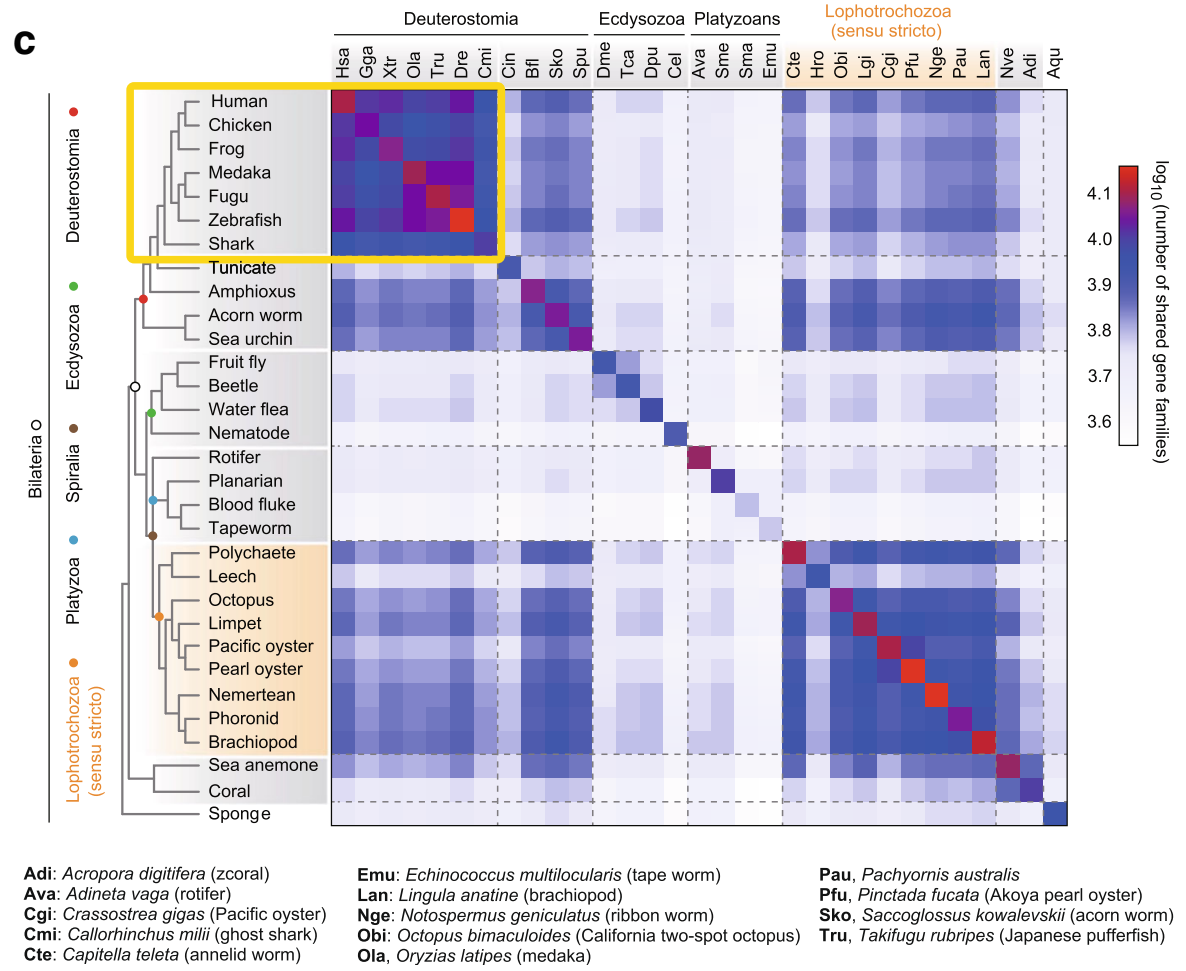

Fig. 4 Clustering of metazoan gene family composition. Shown are the results of two independent analyses performed by (a) Simakov et al. [35] and (b, c) Luo et al. [61]. The first two principal components are displayed. a Principal component (PC) analysis of annotated gene functions. At least three clusters are evident, namely a vertebrate cluster (far right; solid-line circle); a non-bilaterian metazoan, invertebrate deuterostome, or spiralian cluster (center, top; dashed-line circle), and an ecdysozoan group (lower left). Drosophila and Tribolium (lower left) are outliers. b PC analysis of PANTHER gene family sizes. Invertebrate deuterostomes (Bfl, Sko, and Spu) cluster with lophotrochozoans (dashed-line circle). Solid-line circle denotes the clustering of vertebrates. In addition to the metazoan species analyzed in (a), the following species were included in the analysis. c Matrix of shared gene families among selected metazoans. The cladogram on the left is based on phylogenetic positions inferred from this study. Dashed lines separate the major clades. Note that tunicates (Cin) and leeches (Hro) share fewer genes with other bilaterians, probably because of their relatively high evolutionary rates and gene loss in each lineage 
model holds true for each animal phylum. Specifically, for vertebrate species, the transcriptomically identified, most conserved mid-embryonic stages (Fig. 5, left) did have morphological elements that were shared among chordates, such as a dorsal nerve cord and notochord. However, none of the previous studies covered non-vertebrate chordates to see whether these stages could still be identified as the most chordate-conserved stages. Levin et al. [76], in cross-phylum comparisons using 10 animals from different phyla (single species from poriferans, cnidarians, nematodes, arthropods, chordates, echinoderms, annelids, platyhelminths, ctenophores, and tardigrades), observed no mid-embryonic conservations, although Dunn et al. [77] raised methodological concerns regarding their study.

In a comparative transcriptome study reported by $\mathrm{Hu}$ et al. [63], eight chordate species, including two non-vertebrate chordates, were analyzed. Mid-embryonic conservation was robustly supported among the vertebrate species, as in previous studies, but the results for the chordates were not concordant among the methods of transcriptome comparison. In short, analysis of strictly conserved 1:1 orthologous genes (1704 in total) in the eight chordate species revealed that the mid-embryonic phase was transcriptomically conserved (including in the two non-vertebrates: C. intestinalis at around stages 22 to 27 and B. floridae at around the neurula to early larval stages); the identified stages showed a set of chordate body plans, namely the notochord and dorsal nerve cord. However, when paralogous genes and genes lost in certain species were taken into consideration in the transcriptomic comparison, mid-embryonic conservation was not observed among chordate species. These results imply that conserved genes retained since chordate common ancestors are still expressed in the mid-embryonic phase of $C$. intestinalis and amphioxus, but that the overall degree of conservation becomes obscure when lost and duplicated genes are taken into consideration. The conservation boundary between vertebrates and non-vertebrate chordates appears to coincide well with both the 2R-WGD that occurred in the vertebrate lineage, as well as with the morphological differences between vertebrates and non-vertebrate chordates (e.g., the pharyngeal arch in vertebrates and gill slit in Ciona).

Interestingly, the conserved stages found among vertebrates largely overlapped with those conserved in smaller groups, such as tetrapods and amniotes, and even among Хenopus frogs or between turtle and chicken. This persistent conservation [78, 79] suggests that these phases of organogenesis in vertebrates

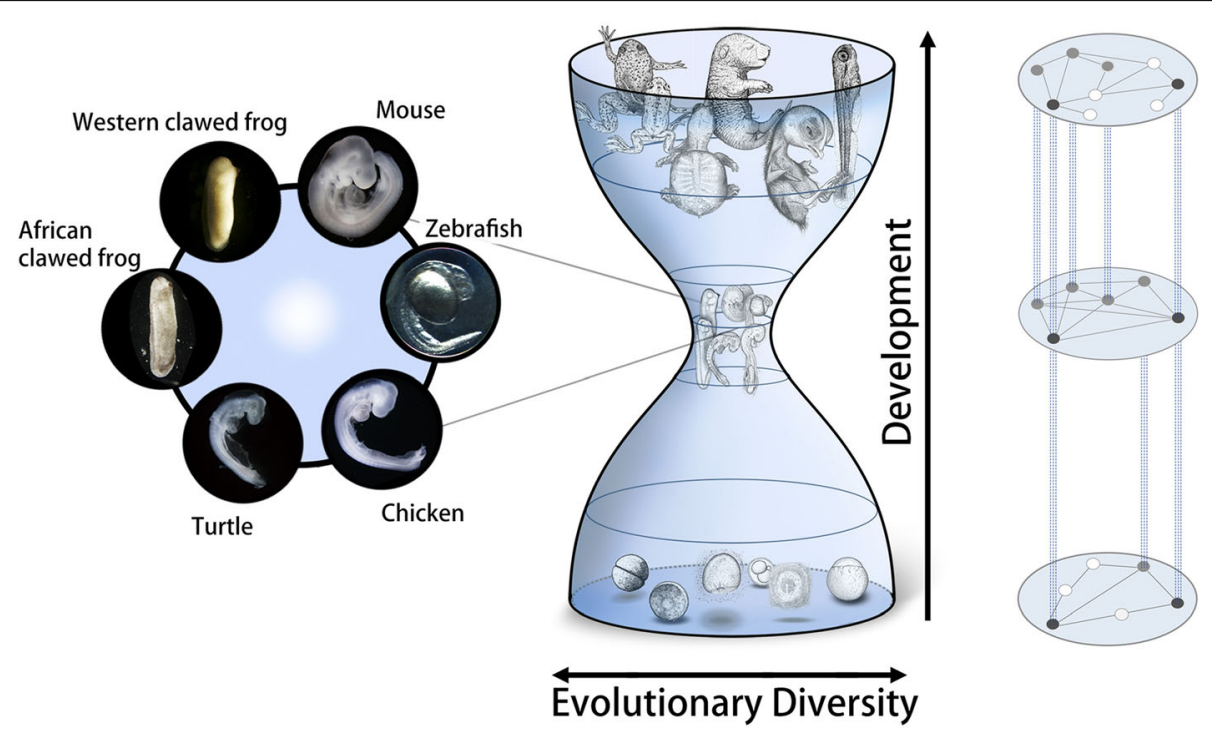

Fig. 5 The developmental hourglass model and embryos representative of phylotypic periods in vertebrates. In the developmental hourglass model (middle, originally proposed by Duboule [64]), embryogenesis proceeds from the bottom to the top, and evolutionary divergence becomes minimal at the mid-embryonic, organogenesis phase. The conserved mid-embryonic phase has been predicted to define the body plan for each animal phylum [64] and has therefore been named the phylotypic satage $[64,65,66,181]$. However, further studies are required to fully verify this hypothesis, and a recent study indicated that the hypothesis may be better applied to vertebrates than to chordates [63]. Embryos representative of most conserved vertebrate stages are shown at the left. Curiously, these stages can also be identified as the most conserved stages when comparing groups of species smaller than at the vertebrate level. No consensus has been reached on the mechanism of this mid-embryonic conservation, but two independent studies have implied possible contributions by developmental constraints [63, 74]. In other words, extensive reuse of the same genetic machinery could have imposed limitations on the evolutionary diversification process through pleiotropic constraint (right, modified from Hu et al. [63]). In each developmental stage, grey and black dots represent genetic components that are pleiotropically expressed in other stages and are shared (blue vertical lines) by multiple developmental processes 
remained targets of conservation since the emergence of their common ancestors. Put differently, this provides an alternative way of defining a phylum by grouping species that show persistent conservation of the same developmental phase, as the highly conserved mid-embryonic phase represents the body plan of a given group. $\mathrm{Hu}$ et al. [63] imply that vertebrates can better be grouped as a phylum than under the chordate phylum. We still do not know whether this can be applied to other animal groups, but independent studies have reported mid-embryonic conservation in species other than chordates in groups much smaller than a phylum (Drosophila genus [72], and Caenorhabditis species and their experimental lineages [73, 74]).

Further studies are required to fully test the idea of defining body plans by persistent conservation of the mid-embryonic phase, because early-diverged vertebrates, such as the lamprey and hagfish, have not yet been included in such investigations. Furthermore, even if pharyngula embryos show persistent conservation within vertebrate lineages, we do not know how that conservation took place. Although the contributions of negative and positive selection per se appear insufficient to explain mid-embryonic conservation $[74,80]$ ), contributions by other mechanisms, such as developmental burden [74] and pleiotropic constraint [72] (Fig. 5, right) are being suggested by experimental studies. Investigating how animals appear to have broken the rule of body plan could also help us to better understand this question [81]. Moreover, identification of the general mechanism behind the hourglass-like conservation model in future studies would be a great help in better understanding the body plans found in various animal groups and in classifying phyla.

\section{Body plan and embryogenesis}

Vertebrates are characterized by a number of specific, derived features that are not found in non-vertebrate chordates or invertebrates. Examples include a well-developed cranium (or head), vertebrae, paired eyes accompanied by extrinsic eye muscles, median fins, a ventrally opening mouth, and a postanal tail (reviewed in [82-84]). The presence of trunk-specific myotomes could also be vertebrate-specific. Other basic characters, including a dorsal neural tube, pharynx with gill pores (or slits), and notochord, are more widely distributed among chordates. Importantly, the gill slits or gill pores are also shared by ambulacrarians, representing a synapomorphy for deuterostomes, not for chordates [35, 83].

Embryologically, the vertebrate pharyngula-the vertebrate embryo at about the organogenetic period-has been regarded as exhibiting the most conserved embryonic pattern (see below), and the development of the vertebrate body plan is thought to be laid upon the establishment of this embryonic pattern (see [64, 85]). The pharyngula is characterized by the presence of ectomesenchyme-containing pharyngeal arches in the ventral head; these are also unique in vertebrates (reviewed in [86-88]; for the development and evolution of the pharyngeal arches, see [89]).

In the pharyngula, we find not only specific sets of organs and embryonic primordia, but also vertebrate-specific integration and connection of elements, each of which occupies its specific and equivalent position in the body and shows a constrained linkage with other elements. For this constraint, a specific set of morphological homologies becomes recognizable. This anatomical integration-the body plan mentioned abovebecomes first visible at the phylotypic period when the phylum-specific developmental constraints become embodied (see [90, 91] for reviews). The interesting question, therefore, is whether there is a chordate-specific body plan in terms of developmental and anatomical patterns, and whether it can be derived through modification of the chordate body plan. We need also to determine whether the vertebrate body plan should be viewed as merely a variation of the chordate body plan, or whether it is distinct enough to establish an independent phylum.

\section{The vertebrate-specific pattern}

On the basis of the presence of the notochord, Kowalevsky recognized close affinity among tunicates, amphioxus, and vertebrates $[9,10]$. Ernst Haeckel was strongly influenced by this theory, and he classified amphioxus as a vertebrate [92]. To distinguish the true vertebrates (as defined at the time) from the amphioxus, he created a subcategory, the craniates (animals with a head), as opposed to the acraniate amphioxus. Thus, craniates were once an in-group of "vertebrates," defined by Haeckel, which were defined similarly to today's Chordata. Subsequently, the name Vertebrata began to be applied only to animals with backbones, as is currently understood (reviewed in [17]). Until recently, amphioxus and hagfish were technically called "invertebrates" [93-95]. To stress the similarity between hagfish and other vertebrates-especially to stress the possession of an overt head-the name Craniata was secondarily applied to mean "vertebrates plus hagfish." At that point, therefore, vertebrates were defined as an in-group of craniates [93-95].

Recently, molecular analyses have unanimously supported the monophyly of cyclostomes (lampreys and hagfishes), and the taxonomic name Craniata has become invalid [96-102] (reviewed in [103]). The morphological definition of vertebrates largely relies on an understanding of hagfish, of course: Besides the absence of vertebral elements, the anatomy of the hagfish is very different from that of other vertebrates. 
Since 2007, our knowledge about hagfish development has been greatly improved, and it is now known that the hagfish develops vestigial vertebral elements, and that the developmental patterns of this animal and the lamprey are very strikingly similar during the early pharyngula period. These animals develop cyclostome-specific anatomical patterns not shared by modern jawed vertebrates, with complicated patterns of chondrocrania that are perfectly comparable between the two animals [104, 105] (reviewed in [103]). The morphological difference between the crown gnathostomes and cyclostomes stems primarily from the transition from single (cyclostomes) to double (crown gnathostomes) nostrils that resulted in a modified distribution of the craniofacial ectomesenchyme $[106,107]$. Otherwise, however, the embryonic patterns of cyclostomes and crown gnathostomes are very similar. In the pharyngula (which is specific to vertebrates, including the cyclostomes), a set of morphological traits is consistently found across species; this includes somites with somitomeric elements, head mesoderm, neural-crest-derived ectomesenchyme, pharyngeal arches and associated branchiomeric structures, and placodes and their derivatives [108, 109].

Vertebrates also have a unique and specific body plan not shared by other chordates. It is noteworthy that von Baer (1828) called the pharyngula the Haupttyp (meaning 'major type') [85], implying that the conceptual archetypal pattern of vertebrates is embodied therein, not as an idealistic pattern but in actual embryonic morphology. The spirit of this nomenclature is that the most basic set of structures for defining vertebrates appears at this particular stage-the phylum-defining stage-emerging at a specific period in the developmental timetable and followed by more specialized stages that define lower ranks of taxa. Von Baer, who did not believe in evolution, thought that developmental patterns reflected the nested relationships of hierarchical taxa. To evaluate the vertebrate phylotype, therefore, it is necessary to characterize the vertebrate pharyngula from the embryological and morphological perspectives. Importantly, Haeckel included amphioxus in vertebrates owing to the resemblance of adult anatomy, not embryonic patterns, to the idealized pattern of vertebrates; amphioxus embryos were compared mainly with cnidarians [108]. Although tunicates are phylogenetically regarded as the lineage closest to the vertebrates (see above), acraniates (amphioxus) are generally thought to represent the best proxy for understanding the origin of the vertebrate body plan, because tunicate developmental patterns are secondarily modified [109]. Therefore, in this section we examine amphioxus as a model for examining the uniqueness of the vertebrate body plan.

As noted above, the definition of the group Vertebrata is tightly linked with the evolutionary origin of the unique head (or cranium), which is absent from amphioxus, and characterizes most clearly the morphological quality and evolutionary origin of the vertebrate body plan per se. Curiously, the vertebrate head develops on the basis of vertebrate-specific cell lineages-the neural crest, along with ectodermal placodes and nonsegmented head mesoderm, none of which is found in non-vertebrate chordates [56, 110]. The evolutionary origin of the neural crest cell lineage has been studied intensively for the past decade, because its acquisition is expected to yield indirect insights into the origin of the head [111-118]). Simultaneously, it has been stressed by Linda Holland and her colleagues that the amphioxus has primarily a rostral end identical to that in vertebrates, in terms of developmental regulatory gene expression profiles; nothing had to be added in the rostral end of the hypothetical ancestor to acquire the vertebrate head [119-123] (also see [124]). We revisit this issue below in a different context of vertebrate morphogenesis.

It seems likely that the evolution of the vertebrate head involved radical changes in developmental programs and the rewiring of associated gene regulatory networks (see [115]). However, the identification of truly vertebrate-specific features is not always straightforward, especially because the precursors of traits can often be found in non-vertebrate chordates $[105,111]$. (For a similar argument regarding evolutionary precursors, see [124].)

\section{Head}

The head mesoderm is unique in vertebrates in that it arises as a non-segmented mesoderm. The morphological and evolutionary origin of the head mesoderm is enigmatic, and historically this question is tightly linked to the idea of head segmentation [125-127]. Whether or not the vertebrate head mesoderm is homologous to the rostral somite (or somites) of amphioxus, the lack of overt mesodermal segments in the vertebrate head provides the vertebrate-specific embryonic environment and distinct morphology of the cranial nerves in these animals ([125]; also see [126]). Unlike the somite-dependent somitomeric organization of the spinal nerves, pharyngeal-arch-associated nerves (branchiomeric nerves) develop on rhombomeres (segmental bulges of the hindbrain) and are distally associated with the epibranchial placode, exhibiting metameric patterns that collectively mirror the branchiomeric segmental pattern of vertebrates. Thus, the vertebrate body plan is characterized by the possession of dual (or triple, including enigmatic neuromeres) metamerism that is most evident in the morphology of the peripheral nervous system [125, 127, 128].

The vertebrate head mesoderm is the source of extrinsic eye muscles and the primary neurocranium that 
encapsulates the enlarged brain [108, 129, 130]. (For development of the extrinsic eye muscles, see [131].) The latter skeletal element is unsegmented, as opposed to the ventral moiety of the cranium, the viscerocranium, which is derived from the neural crest cells in the segmented pharyngeal arches $([130,132]$, but see $[125,133,134])$. Part of the viscerocranium is secondarily incorporated into the neurocranium to form its rostral part in jawed vertebrates (reviewed in $[108,135]$ ). Thus, the vertebrate cranium has two major components, derived from multiple cell lineages and differentiating into various types of skeletal tissues ([136]; also see $[137,138])$.

Unlike vertebrates, amphioxus shows striking asymmetry in both adult morphology and embryonic developmental patterns. For example, its mouth opens on the left side of the embryo, but shifts secondarily to a pseudo-symmetrical position in the adult (asymmetry is still evident in the innervation pattern of the oral hood). Hatschek's pit-the suggested homolog of the adenohypophysis-also develops on the left side, and in the adult, myotomes on the left and right sides show a staggered pattern of arrangement along the body axis [139141]. Amphioxus does not possess a cranium of any sort, nor any skeletal tissues comparable to those in vertebrates. It also develops pharyngeal pores-on the left side only at first-which secondarily become bilaterally paired, each pore being duplicated anteroposteriorly, to result in numerous gill slits [139]. (Also see [140].) These pores never penetrate to open onto the surface in the adult, because a coelom-like structure lined by ectoderm-the peribranchial coelom-secondarily arises by the ventral growth of the left and right atrial folds, which fuse together in the ventral midline leaving a posterior opening, the atriopore. Only early in its development ( $48 \mathrm{~h}$ post-fertilization), therefore, does the amphioxus larva show externally opened pharyngeal pores, and only in the rostral-most part of the pharynx.

Somites grow ventrally into the abovementioned secondary body wall; therefore, on the surface of the amphioxus body, only a single metamerism is apparent externally $[139,141]$. Thus, the vertebrate-like configuration of the pharyngeal pore is found only at the early phase of pharyngeal development, in the rostral-most part of the pharynx. Importantly, all the peripheral nerves pass between the adjacent myotomes-reminiscent of the cyclostome spinal nerves in part. They are regarded as somitomeric nerves as far as their morphology is concerned. (For the functional properties of the nerves, see [142]).

The morphological pattern of the vertebrate head cannot be derived from the amphioxus-like condition. Typically, the position of the mouth is one of the most enigmatic elements to understand. In vertebrates, the mouth arises by the perforation of the oropharyngeal membrane, a composite of pharyngeal endoderm and stomodeal ectoderm, located in the ventral midline of the head ectoderm. This feature, however, is not universal among chordates. Kaji et al. [143] have recently suggested that the amphioxus mouth, which opens on the left side of the body, is very similar to the external duct of the mesodermal coelom as found in echinoderm auricularian larvae. Histological observation and gene expression patterns are consistent with this interpretation [143].

\section{Head-trunk interface and neural crest cells}

In the vertebrate pharyngula, trunk somites are restricted to posterior to the otic vesicle; rostral to the vesicle there is non-segmental head mesoderm (Fig. 6a-d). The cephalic neural crest cells migrate along a pathway called the dorsoventral pathway, which is available only at the somite-free levels. Ventrally, the cephalic crest cells are distributed in each pharyngeal arch, thereby forming an extensive ectomesenchyme as the source of cranial skeletal tissues and other types of connective tissues.

In the trunk of the pharyngula, the neural crest cells are segmented into a metameric pattern by the presence of somites (Fig. 6a-c). In amniotes, in which the behavior of the neural crest cells has been extensively studied, the crest cells are allowed to pass through only the rostral half of a somite, where part of the crest cell population will differentiate into dorsal root ganglia. This trunk-specific pathway is called the ventrolateral pathway, and it mirrors the morphological patterns of the spinal nerves and sympathetic nervous system.

In the postoptic region, there is an intermediate domain between the head and trunk of the pharyngula; this domain is called the head-trunk interface (Figs. 6 and 7). Because the rostral-most somites (suprapharyngeal somites) and caudal (postoptic) pharyngeal arches overlap each other dorsoventrally, at the level caudal to the otic vesicle the head- and trunk-like embryonic environments overlap to form an S-shaped interface. In this domain, the crest cells are distributed in a complex pattern. Some of the postoptic crest-derived cells behave as trunk crest cells, forming vestigial dorsal root ganglia (Froriep's ganglia) associated with the developing hypoglossal nerve, a bundle of secondarily modified spinal nerves [141, 142]. Other crest cells derived from the same axial level pass through the dorsolateral migratory pathway, being excluded from the region occupied by myotomes to form an arch-like pathway opening posteriorly (reviewed in [108]).

The above-described interface is formed primarily by the rostral-most somite and caudal-most part of the pharynx (Fig. 6), each representing, in the body of the 

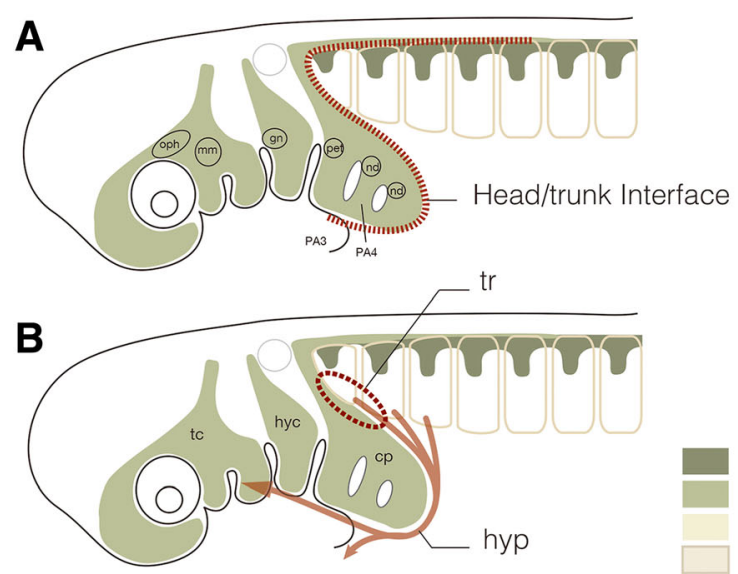

trunk neural crest cells cephalic neural crest cells the domain defined as 'head' segmented dorsal mesoderm pharyngeal pouches or slits
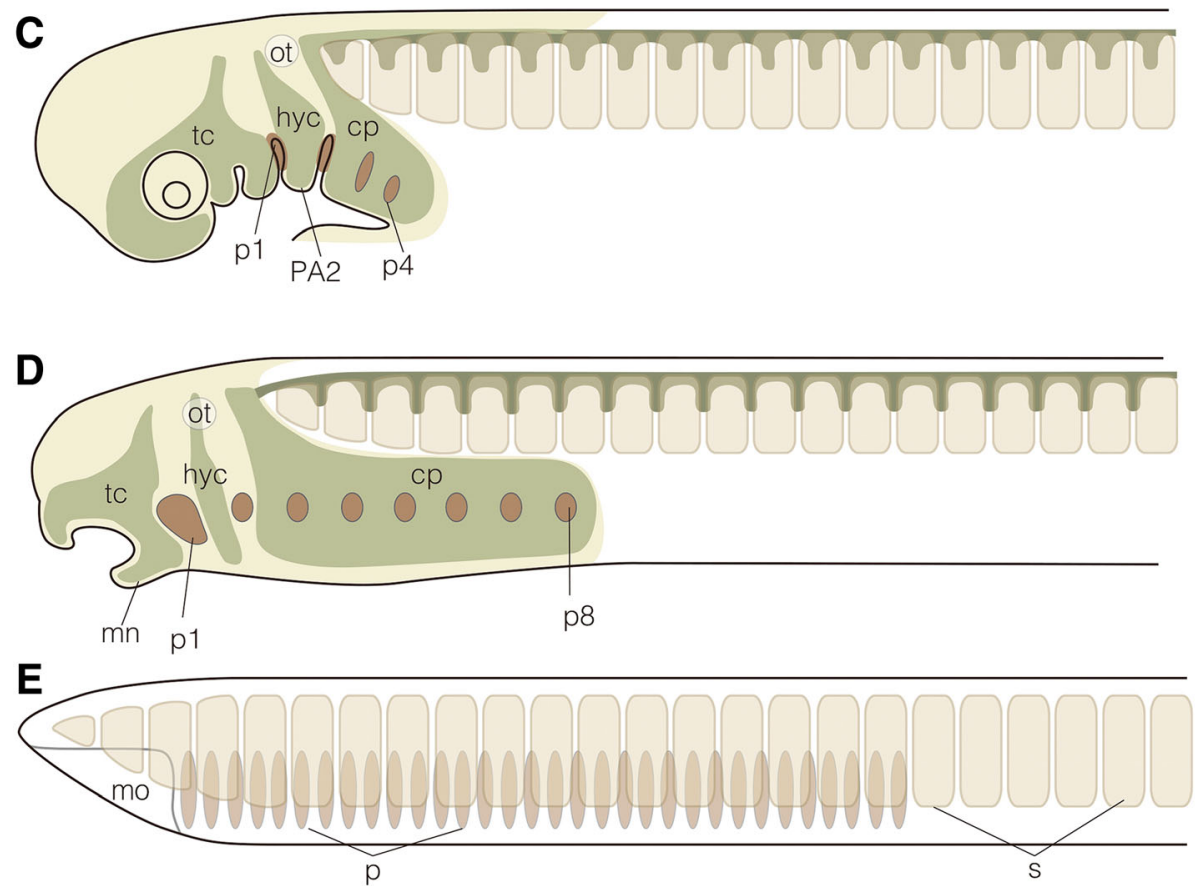

Fig. 6 Head-trunk interface. a to c. Schematic representation of the head and trunk in the pharyngula of modern jawed vertebrates, as defined by the migratory/distribution patterns of neural crest cells (NCCs). In the head of the vertebrate pharyngula, NCCs form extensive ectomesenchyme with three major NCC populations, called trigeminal (tc), hyoid (hyc) and circumpharyngeal crest cells (cp), filling the frontonasal region and pharyngeal arches, defining the vertebrate head (yellowish region in C), as opposed to the posterior domain occupied by somites and the lateral plate. In the trunk, NCCs are segmented primarily into somitomeric streams by the presence of somites (dark green). Between the two distinct groups of NCC populations is found an S-shaped interface (red broken line). Circles denote placodes for cranial nerves (oph, ophthalmic placode; mm, maxillomandibular placode; gn, geniculate placode; pet, petrosal placode; nd, nodose placodes). In B, the position of trapezius muscle development (tr) and pathway of the hypobranchial muscle (the hypoglossal cord: hyp) are shown along the head-trunk interface. $\mathbf{d}$. Schematization of an early lamprey larva. Note that the head and trunk can be defined in this animal as a vertebrate-specific feature. e. Comparison with schematized amphioxus. The mesoderm of this animal is entirely segmented into somite-like structures, but there is no overt lateral plate. Because the pharynx is located medial, not ventral, to the body wall, the head-trunk interface cannot be defined in this animal. mn, mandibular arch; mo, mouth; ot, otic vesicle; p, pharyngeal pores in amphioxus; p1 to 8, pharyngeal pouches; PA2 to 4, pharyngeal arches; s, somites

pharyngula, the rostral end of the trunk environment and the caudal end of the head environment, respectively. Thus, the hypoglossal nerve, a trunk component, circumvents the pharyngeal arches by passing along the ventral curve of the interface, and the proximal part of the vagus nerve, a head component, passes along the dorsal curve to circumvent the trunk environment (Fig. 6). This curious morphological pattern reflects the vertebrate-specific plan of morphogenetic logics, showing unique sets of structures found only in vertebrates. 


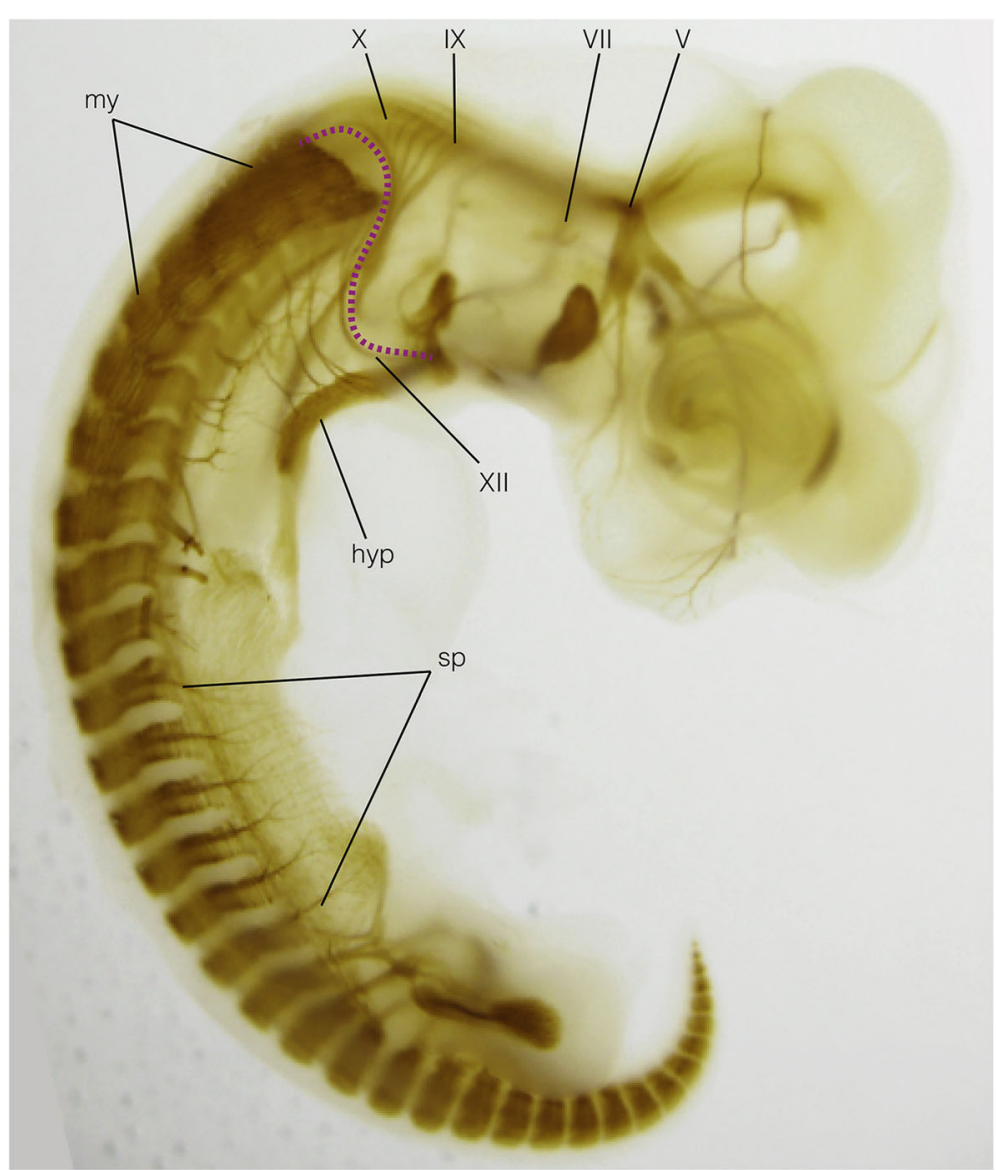

Fig. 7 Late pharyngula of the Chinese soft-shelled turtle, Pelodiscus sinensis, immunostained to show peripheral nervous system and muscle primordia. The head-trunk interface is shown by the magenta broken line, delineating the spinal and branchiomeric nerves from each other. Note also that the myotomes are restricted to the trunk region of the embryo. Hyp, hypobranchial muscle anlage; IX, glossopharyngeal nerve; my, myotomes; sp., spinal nerves; $V$, trigeminal nerve; VII, facial nerve; $X$, vagus nerve; XII, hypoglossal nerve

Around the abovementioned interface, vertebrate-specific structures appear, including the so-called neck (circumpharyngeal) muscles and the nerves to innervate these muscles [125, 144-146]. From the ventral part of the rostral somite-derived muscle plates, migrating muscle precursors are derived to migrate toward the ventral head region along the course of the hypoglossal nerve. These muscles, called the hypobranchial muscles, are vertebrate specific and are also found in cyclostomes, in a primitive form [147]. As the dorsal element of the circumpharyngeal muscles, the cucullaris muscle and its nerve, the accessory nerve, are recognized as derived traits that define gnathostomes. (See [148]; also see [128].) All these features arise in the unique embryonic environment established at the interface between the vertebrate head and trunk; this environment is not found in amphioxus (Fig. 6e).

Unlike the vertebrate pharyngeal arches, the amphioxus pharyngeal wall is independently separated medially from the wall that forms the ventral surface of the body. Myotomes penetrate into this pseudo-body wall, and there is no lateral plate-like continuous sheet of mesoderm. In this pattern of structural integration, unlike in vertebrates, the rostral "somites" never contact the pharyngeal wall, and therefore the head-trunk interface does not form. Thus, the latter interface is truly vertebrate specific, together with the structures patterned by this interface, including the hypobranchial and cucullaris muscles and the accessory, vagus, and hypoglossal nerves.

\section{Somites and myotomes}

There has been a long-standing prediction that the vertebrate head mesoderm evolved from the rostral segmented mesoderm of ancestral forms such as amphioxus $([129,130,149]$. This idea originated from the so-called head segmentation theory that began as the vertebral theory of the skull proposed in the early nineteenth century by Oken [150] and Goethe [151], and before that by Vicq d'Azyr [152]. This originally 
transcendental idea was further strengthened by the discovery of epithelial coelom-like structures called head cavities in some primitive jawed vertebrates such as elasmobranchs and holocephalans ([153, 154]; reviewed in [155]). However, it has also been suggested that the head cavities represent a gnathostome synapomorphy, and that their epithelial segment-like configuration has nothing to do with the hypothetical head somites: there is no substantial difference in gene expression profiles between the head cavities and non-segmented, mesenchymal head mesoderm [156, 157] (reviewed in [155]).

On the basis of accumulated data on the gene expression profiles in developing paraxial mesoderm, however, it has become clear that amphioxus somites are not necessarily more similar to vertebrate somites than to head mesoderm, but they share gene expression profiles known to be specific to the vertebrate head mesoderm (reviewed in [156, 157]). Experimentally, as well, amphioxus somites are not necessarily closer to vertebrate trunk somites than to head mesoderm; it is possible that they represent an intermediate structure $[158,159]$. (Also see [125] for a comparative embryological discussion).

The above arguments are based on the assumption that the common ancestor of amphioxus and vertebrates possessed an anteroposteriorly elongated body, with segmental mesodermal blocks throughout the entire axis. This assumption, however, has not been substantiated, although it may be relevant to the origin and homology of segments across bilaterians.

Masterman [160] once tried to identify the origin of metameric segments in three pairs of coelomic cavities derived from gut septations in the jellyfish. (Also see [161-163].) According to this scheme, the prototypic bilaterian mesodermal cavities have three components, the rostral-most one of which is found in the procoels in various bilaterian larvae, including the actinotrochs of phoronids, tornarian larvae of hemichordates, and auricularian larvae of echinoderms. Vertebrate embryos also fall into this category: The premandibular cavity is often assumed to be homologous to the procoel; the head mesoderm is homologous to the mesocoel and the entire somites to the metacoel [163]. If the early embryonic pattern of amphioxus is comparable to this scheme-especially the pattern of echinoderm larvae-then the anterior head diverticulum could represent the procoel of auricularians, and the rostral-most triangular somite would represent the mesocoel. (For other interpretations, see [164].) This level of comparison, however, potentially refers to the pan-bilaterian coelomic developmental program, not necessarily the chordate-specific morphotype. In addition, even if mesodermal homology between vertebrates and amphioxus could be established definitively, it would not mean that their body plans are identical, because the anteroposteriorly polarized distribution of the different generative constraints that yield the somitomeric and branchiomeric patterns in vertebrates is not present in amphioxus.

From the above, it is clear that the vertebrate body plan cannot have been derived from an amphioxus-like ancestor by continuous modification. The two animal groups possess conspicuous morphotypes that are distinctly different from each other: The homology of the mouth is lost, and the topographic relationship between somites and pharynx changes, during the early evolution of chordates, giving rise to different body plans. Chordates share only the notochord, postanal tail, and dorsal nerve chord as synapomorphies, because of the shared evolutionary history of dorsoventral inversion. However, the body plans of the three chordate lineages are as different as those found in each of the phyla among ambulacrarians, lophotrochozoans, or ecdysozoans. Given their distinct set of morphological patterns and elements, vertebrates are more appropriately classified as an independent phylum.

\section{Conclusion}

Metazoan taxonomy and systematics, which are basic and important issues in zoology, provide basic information to help researchers interpret the grouping of various animal species. We believe that taxonomic interpretation must always be reexamined when new data are presented-especially new molecular data from different disciplines-as such comprehensive analyses are likely to inform more balanced decisions on classification. Here, we have discussed the possibility that Vertebrata should be recognized as an animal phylum. In light of the present subphylum rank of the Vertebrata, recognition of this possibility would facilitate future studies of the origin and evolution of vertebrates.

\section{Acknowledgements \\ This work was supported by a Grant-in-Aid for Scientific Research on Innovative Areas (Research in a Proposed Research Area; no. 17H06385) and a Naito Grant for the Promotion of Focused Research (The Naito Foundation) to S.K., a Grant-in-Aid for Scientific Research (B) (no. 16H04824) to N.S., and a Grant-in-Aid for Scientific Research on Innovative Areas (Research in a Proposed Research Area; no. 17H06387) to N.I. \\ Funding \\ See Acknowledgements.}

Availability of data and materials Not applicable.

Authors' contributions

All three authors designed the review. NS contributed mainly sections 1 and 2 , SK section 3, and N.I. section 4. All authors prepared the manuscript.

Ethics approval and consent to participate

Not applicable.

Consent for publication

Not applicable. 


\section{Competing interests}

The authors declare that they have no competing interests.

\section{Publisher's Note}

Springer Nature remains neutral with regard to jurisdictional claims in published maps and institutional affiliations.

\section{Author details}

'Department of Biological Sciences, School of Science, University of Tokyo, Tokyo 113-0033, Japan. ${ }^{2}$ Universal Biology Institute, University of Tokyo, Tokyo 113-0033, Japan. ${ }^{3}$ Marine Genomics Unit, Okinawa Institute of Science and Technology Graduate University, Onna, Okinawa 904-0495, Japan. ${ }^{4}$ Laboratory for Evolutionary Morphology, RIKEN Center for Biosystems Dynamics Research, and Evolutionary Morphology Laboratory, RIKEN Cluster for Pioneering Research, 2-2-3 Minatojima-minami, Chuo-ku, Kobe 650-0047, Japan.

Received: 29 August 2018 Accepted: 5 December 2018 Published online: 26 December 2018

\section{References}

1. Gee H. Across the bridge: understanding the origin of the vertebrates Chicago: The University of Chicago Press; 2018.

2. Aristotle: 'Historia Animalium': Volume 1, Books I-X: Text (Cambridge Classical Texts and Commentaries) 2011.

3. Balfour FM. A treatise on comparative embryology. London: Macmillan; 1880. p. 1881

4. Yarrell WA. History of British fishes. Vol. 1 and Suppl. London: John Van Voorst; 1836.

5. Huxley TH. Observations upon the anatomy and physiology of Salpa and Pyrosoma. Philos Trans R Soc. 1851;part ii:567-594.

6. Lamarck JB. Recherches sur les causes des principaux faits physiques. Paris: Tome Second; 1794

7. Darwin C. On the origin of species. London: Murray; 1859.

8. Haeckel E. Generelle morphologie der organismen. Berlin. Germany: Verlagvon Georg Reimer; 1866.

9. Kowalevsky A. Entwicklungsgeschichte der einfachen Ascidien. Mem Acad St Petersbourg Ser. 1866;(7)10;7:1-19.

10. Kowalevsky A. Entwicklungsgeschichte des Amphioxus lanceolatus. Mem Acad St Petersbourg Ser. 1867;(7)11;7:1-17.

11. Lankester ER. Notes on the embryology and classification of the animal kingdom: comprising a revision of speculation relative to the origin and significance of germ layers. Quart J Microsc Soc. 1877:17:399-454.

12. Aguinaldo AM, Turbeville JM, Linford LS, Rivera MC, Garey JR, Raff RA, Lake JA. Evidence for a clade of nematodes arthropods and other moulting animals. Nature. 1997;387:489-93.

13. Dunn CW, Hejnol A, Matus DQ, Pang K, Browne WE, Smith SA, Seaver E, Rouse GW, Obst M, Edgecombe GD, Sørensen MV, Haddock SH, SchmidtRhaesa A, Okusu A, Kristensen RM, Wheeler WC, Martindale MQ, Giribet G. Broad phylogenomic sampling improves resolution of the animal tree of life. Nature. 2008;452:745-9.

14. Swalla BJ, Cameron CB, Corley LS, Garey JR. Urochordates are monophyletic within the deuterostomes. Syst Biol. 2000;49:122-34.

15. Zeng L, Swalla BJ. Molecular phylogeny of the protochordates: chordate evolution. Can J Zool. 2005;83:24-33.

16. Satoh N, Rokhsarm D, Nishiakawa T. Chordate evolution and the threephylum system. Proc Roy. Soc. B. 2014;281:20141729.

17. Satoh N. Chordate origins and evolution. NY: Academic Press; 2016.

18. Ryan JF, Pang K, Schnitzler CE, Nguyen AD, Moreland RT, Simmons DK, Koch BJ, Francis WR, Havlak P. NISC comparative sequencing program, Smith SA Putnam NH, Haddock SH, Dunn CW, Wolfsberg TG, Mullikin JC, Martindale MQ, Baxevanis AD. The genome of the Ctenophoe Mnemiopsis leidyi and its implications for cell type evolution. Science. 2013;342:1336-45.

19. Moroz LL, Kocot KM, Citarella MR, Dosung S, Norekian TP, Povolotskaya IS, Grigorenko AP, Dailey C, Berezikov E, Buckley KM, Ptitsyn A, Reshetov D, Mukherjee K, Moroz TP, Bobkova Y, Yu F, Kapitonov W, Jurka J, Bobkov YV, Swore JJ, Girardo DO, Fodor A, Gusev F, Sanford R, Bruders R, Kittler E, Mills CE, Rast JP, Derelle R, Solovyev W, Kondrashov FA, Swalla BJ, Sweedler JV, Rogaev El, Halanych KM, Kohn AB. The ctenophore genome and the evolutionary origin of neural systems. Nature. 2014;510:109-14.
20. Philippe $H$, Brinkmann $H$, Copley RR, Moroz LL, Nakano H, Poustka AJ, Wallberg A, Peterson KJ, Telford MJ. Acoelomorph flatworms are deuterostomes related to Xenoturbella. Nature. 2011;470:255-8.

21. Nielsen C. Animal evolution: interrelationships of the living phyla. New York: Oxford University Press; 1995.

22. Halanych KM, Bacheller JD, Aguinaldo AM, Liva SM, Hillis DM, Lake JA. Evidence from 185 ribosomal DNA that the lophophorates are protostome animals. Science. 1995;267:1641-3.

23. Laumer CE, Bekkouche N, Kerbl A, Goetz F, Neves RC, Sørensen MV, Kristensen RM, Hejnol A, Dunn CW, Giribet G, Worsaae K. Spiralian phylogeny informs the evolution of microscopic lineages. Curr Biol. 2015;25:2000-6.

24. Brusca RC, Brusca GJ. Invertebrates. 2nd ed. Massachusetts: Sinaur Associates; 2003.

25. Struck TH, Paul C, Hill N, Hartmann S, Hösel C, Kube M, Lieb B, Meyer A, Tiedemann R, Purschke G, Bleidorn C. Phylogenic analyses unravel annelid evolution. Nature. 2011:471:95-8.

26. Alföldi J, Di Palma F, Grabherr M, Williams C, Kong L, Mauceli E, Russell P, Lowe CB, Glor RE, Jaffe JD, Ray DA, Boissinot S, Shedlock AM, Botka C, Castoe TA, Colbourne JK, Fujita MK, Moreno RG, ten Hallers BF, Haussler D, Heger A, Heiman D, Janes DE, Johnson J, de Jong PJ, Koriabine MY, Lara M, Novick PA, Organ CL, Peach SE, Poe S, Pollock DD, de Queiroz K, Sanger T, Searle S, Smith JD, Smith Z, Swofford R, Turner-Maier J, Wade J, Young S, Zadissa A, Edwards SV, Glenn TC, Schneider CJ, Losos JB, Lander ES, Breen M, Ponting CP, Lindblad-Toh K. The genome of the green anole lizard and comparative analysis with birds and mammals. Nature. 2011;477:587-91.

27. International Chicken Genome Sequence Consortium. Sequence and comparative analysis of the chicken genome provide unique perspective on vertebrate evolution. Nature. 2004;432:695-716.

28. Hedges SB, Poling LL. A molecular phylogeny of reptiles. Science. 1999;283: 998-1001.

29. Wada H, Satoh N. Details of the evolutionary history from invertebrates to vertebrates, as deduced from the sequences of 185 rDNA. Proc Natl Acad Sci U S A. 1994:91:1801-4.

30. Halanych KM. The phylogenetic position of the pterobranch hemichordates based on 18S rDNA sequence data. Mol Phylogenet Evol. 1995:4:72-6.

31. Metchnikoff E. Uber die systematische Stellung von Balanoglossus. Zool Anz. 1881:4:153-7.

32. Delsuc F, Brinkmann $H$, Chourrout D, Philippe $H$. Tunicates and not cephalochordates are the closest living relatives of vertebrates. Nature. 2006; 439:965-8.

33. Bourlat $\mathrm{SJ}$, Juliusdottir $\mathrm{T}$, Lowe CJ, Freeman R, Aronowicz J, Kirschner M, Lander ES, Thorndyke M, Nakano H, Kohn AB, Heyland A, Moroz LL, Copley RR, Telford MJ. Deuterostome phylogeny reveals monophyletic chordates and the new phylum Xenoturbellida. Nature. 2006;444:85-8.

34. Putnam NH, Butts T, Ferrier DE, Furlong RF, Hellsten U, Kawashima T, Robinson-Rechavi M, Shoguchi E, Terry A, Yu JK, Benito-Gutiérrez EL, Dubchak I, Garcia-Fernàndez J, Gibson-Brown JJ, Grigoriev IV, Horton AC, de Jong PJ, Jurka J, Kapitonov W, Kohara Y, Kuroki Y, Lindquist E, Lucas S, Osoegawa K, Pennacchio LA, Salamov AA, Satou Y, Sauka-Spengler T, Schmutz J, Shin-I T, Toyoda A, Bronner-Fraser M, Fujiyama A, Holland LZ, Holland PW, Satoh N, Rokhsar DS. The amphioxus genome and the evolution of the chordate karyotype. Nature. 2008:453:1064-71.

35. Simakov O, Kawashima T, Marlétaz F, Jenkins J, Koyanagi R, Mitros T, Hisata K, Bredeson J, Shoguchi E, Gyoja F, Yue JX, Chen YC, Freeman RM Jr, Sasaki A, Hikosaka-Katayama T, Sato A, Fujie M, Baughman KW, Levine J, Gonzalez P, Cameron C, Fritzenwanker JH, Pani AM, Goto H, Kanda M, Arakaki N, Yamasaki S, Qu J, Cree A, Ding Y, Dinh HH, Dugan S, Holder M, Jhangiani SN, Kovar CL, Lee SL, Lewis LR, Morton D, Nazareth LV, Okwuonu G, Santibanez J, Chen R, Richards S, Muzny DM, Gillis A, Peshkin L, Wu M, Humphreys T, Su YH, Putnam NH, Schmutz J, Fujiyama A, Yu JK, Tagawa K, Worley KC, Gibbs RA, Kirschner MW, Lowe CJ, Satoh N, Rokhsar DS, Gerhart J. Hemichordate genomes and deuterostome origins. Nature. 2015;493:526-31.

36. Nossa CW, Havlak P, Yue J-X, LV J, Vincent KY, Brockmann HJ, Putnam NH. Joint assembly and genetic mapping of the Atlantic horseshoe crab genome reveals ancient whole genome duplication. Gigascience. 2014;3:9.

37. Schwager EE, Sharma PP, Clarke T, Leite DJ, Wierschin T, Pechmann M, Akiyama-Oda Y, Esposito L, Bechsgaard J, Bilde T, Buffry AD, Chao H, Dinh $H$, Doddapaneni $H$, Dugan S, Eibner C, Extavour CG, Funch P, Garb J, Gonzalez LB, Gonzalez VL, Griffiths-Jones S, Han Y, Hayashi C, Hilbrant M, Hughes DST, Janssen R, Lee SL, Maeso I, Murali SC, Muzny DM, Nunes da Fonseca R, Paese CLB, Qu J, Ronshaugen M, Schomburg C, Schönauer A, Stollewerk A, Torres-Oliva M, Turetzek N, Vanthournout 
B, Werren JH, Wolff C, Worley KC, Bucher G, Gibbs RA, Coddington J, Oda H, Stanke M, Ayoub NA, Prpic NM, Flot JF, Posnien N, Richards S, McGregor AP. The house spider genome reveals an ancient whole genome duplication during arachnid evolution. BMC Biol. 2017;15:62.

38. Li Z, Tiley GP, Galuska SR, Reardon CR, Kidder TI, Rundell RJ, Barker MS. Multiple large-scale gene and genome duplications during the evolution of hexapods. Proc Natl Acad Sci U S A. 2018;115:4713-8.

39. Garcia-Fernández J, Holland PW. Archetypal organization of the amphioxus Hox gene cluster. Nature. 1994;370:563-6.

40. Ferrier DE, Mingullon C, Holland PW, Garcia-Fernandez J. The amphioxus Hox cluster: deuterostome posterior flexibility and Hox14. Evol Devel. 2000 2:284-93.

41. Amemiya CT, Prohaska SJ, Hill-Force A, Cook A, Wasserscheid J, Ferrier DE, Pascual-Anaya J, Garcia-Fernàndez J, Dewar K, Stadler PF. The amphioxus Hox cluster: characterization, comparative genomics, and evolution. J Exp Zool B Mol Dev Evol. 2008;310:465-77.

42. Cameron CB, Garey JR, Swalla BJ. Evolution of the chordate body plan: new insights from phylogenetic analyses of deuterostome phyla. Proc Natl Acad Sci U S A. 2000;97:4469-74.

43. Freeman R, Ikuta T, Wu M, Koyanagi R, Kawashima T, Tagawa K, Humphreys T, Fang GC, Fujiyama A, Saiga H, Lowe C, Worley K, Jenkins J, Schmutz J, Kirschner M, Rokhsar D, Satoh N, Gerhart J. Identical genomic organization of two hemichordate hox cluster. Curr Biol. 2012;22:2053-8.

44. Cameron RA, Rowen L, Nesbitt R, Bloom S, Rast JP, Berney K, Arenas-Mena C, Martinez P, Lucas S, Richardson PM, Davidson EH, Peterson KJ, Hood L. Unusual gene order and organization of the sea urchin hox cluster. J Exp Zool B Mol Dev Evol. 2006;306:45-58.

45. Baughman KW, McDougall C, Cummins SF, Hall M, Degnan BM, Satoh N, Shoguchi E. Genomic organization of Hox and ParaHox clusters in the echinoderm, Acanthaster planci. Genesis. 2014;52:952-8.

46. Dehal P, Satou Y, Campbell RK, Chapman J, Degnan B, De Tomaso A, Davidson B, Di Gregorio A, Gelpke M, Goodstein DM, Harafuji N, Hastings KE, Ho I, Hotta K, Huang W, Kawashima T, Lemaire P, Martinez D, Meinertzhagen IA, Necula S, Nonaka M, Putnam N, Rash S, Saiga H, Satake M, Terry A, Yamada L, Wang HG, Awazu S, Azumi K, Boore J, Branno M, Chin-Bow S, DeSantis R, Doyle S, Francino P, Keys DN, Haga S, Hayashi H, Hino K, Imai KS, Inaba K, Kano S, Kobayashi K, Kobayashi M, Lee Bl, Makabe KW, Manohar C, Matassi G, Medina M, Mochizuki Y, Mount S, Morishita T, Miura S, Nakayama A, Nishizaka S, Nomoto H, Ohta F, Oishi K, Rigoutsos I, Sano M, Sasaki A, Sasakura Y, Shoguchi E, Shin-i T, Spagnuolo A, Stainier D, Suzuki MM, Tassy O, Takatori N, Tokuoka M, Yagi K, Yoshizaki F, Wada S, Zhang C, Hyatt PD, Larimer F, Detter C, Doggett N, Glavina T, Hawkins T, Richardson P, Lucas S, Kohara Y, Levine M, Satoh N, Rokhsar DS. The draft genome of Ciona intestinalis: insight into chordate and vertebrate origins. Science. 2002;298:2157-67.

47. Spagnuolo A, Ristoratore F, Di Gregorio A, Aniello F, Branno M, Di Lauro R. Unusual number and genomic organization of Hox genes in the tunicate Ciona intestinalis. Genes. 2003:309:71-9.

48. Ikuta T, Yoshida N, Satoh N, Saiga H. Ciona intestinalis Hox gene cluster: its dispersed structure and residual colinear expression in development. Proc Natl Acad Sci U S A. 2004;101:15118-23.

49. Shoguchi $E$, Hamaguchi M, Satoh N. Genome-wide network of regulatory genes for construction of a chordate embryo. Dev Biol. 2008;316:498-509.

50. Duboule D. The rise and fall of Hox gene cluster. Development. 2007;134: 2549-60.

51. Liang D, Wu R, Geng J, Wang C, Zhang P. A general scenario of Hox gene inventory variation among major sarcopterygian lineage. BMC Evol Biol. 2011;11:25.

52. King BL, Gillis JA, Carlisle HR. Dahn RD. a natural deletion of the Hox cluster in elasmobranch fishes. Science. 2011:334:1517.

53. Mungpakdee $S$, Seo HC, Angotzi AR, Dong $X$, Akalin A, Chourrout D. Differential evolution of the 13 Atratic salmon Hox clusters. Mol Biol Evol. 2008:25:1333-43

54. Stadler PF, Fried C, Prohaska SJ, Bailey WJ, Misof BY, Ruddle FH, Wagner GP. Evidence for independent Hox gene duplications in the hagfish lineage: a PCR-based gene inventory of Eptatretus stoutii. Mol Phylogenet Evol. 2004; 32:686-94.

55. Pascual-Anaya J, Sato I, Sugahara F, Higuchi S, Paps J, Ren Y, Takagi W, RuizVillalba A, Ota KG, Wang W, Kuratani S. Hagfish and lamprey Hox genes reveal conservation of temporal colinearity in vertebrates. Nat Ecol Evol. 2018;2:859-66
56. Smith JJ, Keinath MC. The sea lamprey meiotic map improves resolution of ancient vertebrate genome duplication. Genome Res. 2015;25:1081-90.

57. Smith JJ, Timonshevskaya N, Ye C, Holt C, Keinath MC, Parker HJ, Cook ME, Hess JE, Narum SR, Lamanna F, Kaessmann H, Timoshevskiy VA, Waterbury CKM, Saraceno C, Wiedemann LM, Robb SMC, Baker C, Eichler EE, Hockman D, Sauka-Spengler T, Yandell M, Krumlauf R, Elgar G, Amemiya CT. The sea lamprey germline genome provides insights into programmed genome rearrangement and vertebrate evlution. Nat Genet. 2018;50:270-7.

58. Gans C, Northcutt RG. Neural crest and the origin of vertebrates: a new head. Science. 1983;220:268-74.

59. Kargong KV. Vertebrates Comparative anatomy, function evolution. 7th ed. New York: McGraw-Hill; 2009.

60. Simakov O, Marletaz F, Cho SJ, Edsinger-Gonzales E, Havlak P, Hellsten U, Kuo DH, Larsson T, Lv J, Arendt D, Savage R, Osoegawa K, de Jong P, Grimwood J, Chapman JA, Shapiro H, Aerts A, Otillar RP, Terry AY, Boore JL, Grigoriev IV, Lindberg DR, Seaver EC, Weisblat DA, Putnam NH, Rokhsar DS. Insights into bilaterian evolution from three spiralian genomes. Nature. 2013:493:526-31.

61. Luo YJ, Kanda M, Koyanagi R, Hisata K, Akiyama T, Sakamoto H, Sakamoto T, Satoh N. Nemertean and phoronid genomes reveal lophotrochozoan evolution and the origin of bilaterian heads. Nat Eco Evol. 2018;2:141-51.

62. Budd G, Jensen S. A critical reappraisal of the fossil record of the bilaterian phyla. Biol Rev. 2000;75:253-95.

63. Hu H, Uesaka M, Guo S, Shimai K, Lu T, Li F, Fujimoto S, Ishikawa M, Liu S, Sasagawa Y, Zhang G, Kuratani S, Yu J, Kusakabe TG, Khaitovich P, Irie N. The EXPANDE consortium Constrained vertebrate evolution by pleiotropic genes. Nat Ecol Evol. 2018;1:1722-30.

64. Duboule D. Temporal colinearity and the phylotypic progression: a basis for the stability of a vertebrate Bauplan and the evolution of morphologies through heterochrony. Dev Suppl. 1994;1994:135-42.

65. Raff R. The shape of life. Chicago: The university of Chicago press; 1996.

66. Sander K. Specification of the basic body pattern in insect embryogenesis. Adv Insect Physiol. 1976;12:125-238.

67. Hazkani-Covo E, Wool D, Graur D. In search of the vertebrate phylotypic stage: a molecular examination of the developmental hourglass model and von Baer's third law. J Exp Zool B Mol. 2005;304:150-8.

68. Irie N, Sehara-Fujisawa A. The vertebrate phylotypic stage and an early bilaterian-related stage in mouse embryogenesis defined by genomic information. BMC Biol. 2007;5:1.

69. Domazet-Loso T, Tautz D. A phylogenetically based transcriptome age index mirrors ontogenetic divergence patterns. Nature. 2010:468:815-8.

70. Irie N, Kuratani S. Comparative transcriptome analysis reveals vertebrate phylotypic period during organogenesis. Nat Commun. 2011;2:248.

71. Wang Z, Pascual-Anaya J, Zadissa A, Li W, Niimura Y, Huang Z, Li C, White S, Xiong Z, Fang D, Wang B, Ming Y, Chen Y, Zheng Y, Kuraku S, Pignatelli M, Herrero J, Beal K, Nozawa M, Li Q, Wang J, Zhang H, Yu L, Shigenobu S, Wang J, Liu J, Flicek P, Searle S, Wang J, Kuratani S, Yin Y, Aken B, Zhang G, Irie N. The draft genomes of soft-shell turtle and green sea turtle yield insights into the development and evolution of the turtle-specific body plan. Nat Genet. 2013;45:701-6.

72. Kalinka AT, Varga KM, Gerrard DT, Preibisch S, Corcoran DL, Jarrells J, Ohler $\mathrm{U}$, Bergman CM, Tomancak P. Gene expression divergence recapitulates the developmental hourglass model. Nature. 2010;468:811-4.

73. Levin M, Hashimshony T, Wagner F, Yanai I. Developmental milestones punctuate gene expression in the Caenorhabditis embryo. Dev Cell. 2012; 22:1101-8.

74. Zalts $\mathrm{H}$, Yanai I. Developmental constraints shape the evolution of the nematode mid-developmental transition. Nat Ecol Evol. 2017;1:0113.

75. Xu F, Domazet-Lošo T, Fan D, Dunwell TL, Li L, Fang X, Zhang G. High expression of new genes in trochophore enlightening the ontogeny and evolution of trochozoans. Sci Rep. 2016;6:34664.

76. Levin M, Anavy L, Cole AG, Winter E, Mostov N, Khair S, Senderovich N, Kovalev E, Silver DH, Feder M, Fernandez-Valverde SL, Nakanishi N, Simmons D, Simakov O, Larsson T, Liu SY, Jerafi-Vider A, Yaniv K, Ryan JF, Martindale MQ, Rink JC, Arendt D, Degnan SM, Degnan BM, Hashimshony T, Yanai I. The mid-developmental transition and the evolution of animal body plans. Nature. 2016;531:637-41.

77. Dunn CW, Zapata F, Munro C, Siebert S, Hejnol A. Pairwise comparisons across species are problematic when analyzing functional genomic data. Proc Natl Acad Sci U S A. 2018;115(3):E409-17.

78. Irie N, Kuratani $\mathrm{S}$. The developmental hourglass model: a predictor of the basic body plan? Development. 2014;141:4649-55. 
79. Irie N. Remaining questions related to the hourglass model in vertebrate evolution. Curr Opin Genet Dev. 2017;45:103-7.

80. Uchida Y, Uesaka M, Yamamoto T, Takeda H, Irie N. Embryonic lethality is not sufficient to explain hourglass-like conservation of vertebrate embryos. EvoDevo. 2018;9:7

81. Suzuki D. Two-headed mutants of the lamprey, a basal vertebrate. Zool Lett. 2016;2:22.

82. Romer AS, Parsons TS. The Vertebrate Body. 5th ed. Philadelphia: Saunders; 1977.

83. Jefferies RPS. The ancestry of the Vertebrates. In: British museum (natural history); 1986.

84. Schaeffer B. Deuterostome monophyly and phylogeny. Evol Biol. 1987;21: 179-235 (cited in Gee, 1996).

85. von Baer KE. Uber Entwickelungsgeschichte der Thiere. Koenigsberg: Beobachtung und Reflektion; 1828.

86. Noden DM. Craniofacial development: new views on old problems. Anat Rec. 1984;208:1-13.

87. Noden DM. Origins and patterning of craniofacial mesenchymal tissues. J Craniofac Genet Dev Biol Suppl. 1986;2:15-31.

88. Noden DM. Interactions and fates of avian craniofacial mesenchyme. Development. 1988;103:121-40.

89. Shone V, Oulion S, Casane D, Laurenti P, Graham A. Mode of reduction in the number of pharyngeal segments within the sarcopterygians. Zool Lett. 2016;2:6.

90. Carroll RL. Patterns and Processes of Vertebrate Evolution. Cambridge: Cambridge Univ Press; 1997.

91. Rosenberg A. The character concept: Adaptationalism to molecular developments. In: Wagner GP, editor. The character concept in evolutionary biology. Cambridge: Academic Press; 2001. p. 199-214.

92. Haeckel E. Anthropogenie, oder, Entwickelungsgeschichte des menschen. W Engelmann: Keimes-und stammesgeschichte; 1877.

93. Forey $P$, Janvier P. Agnathans and the origin of jawed vertebrates. Nature. 1993:361:129.

94. Janvier P. Early Vertebrates. New York: Oxford Scientific Publications; 1996.

95. Hall BK. The neural crest in development and evolution. New York: Springer Verlag; 1999.

96. Mallatt J, Sullivan J. 28S and 18S rDNA sequences support the monophyly of lampreys and hagfishes. Mol Biol Evol. 1998;15:1706-18.

97. Kuraku S, Hoshiyama D, Katoh K, Suga H, Miyata T. Monophyly of lampreys and hagfishes supported by nuclear DNA-coded genes. J Mol Evol. 1999;49: 729-35.

98. Delarbre C, Gallut C, Barriel V, Janvier P, Gachelin G. Complete mitochondrial DNA of the hagfish, Eptatretsu burgeri: the comparative analysis of mitochondrial DNA sequences strongly supports the cyclostome monophyly. Mol Phylogenet Evol. 2002;22:184-92.

99. Takezaki N, Figueroa F, Zaleska-Rutczynska Z, Klein J. Molecular phylogeny of early vertebrates: monophyly of the agnathans as revealed by sequences of 35 genes. Mol Biol Evol. 2003;20:287-92.

100. Kuraku S. Insights into cyclostome phylogenomics: pre-2R or post-2R? Zoo Sci. 2008;25:960-8.

101. Mallat J, Winchell CJ. Ribosomal RNA genes and deuterostome phylogeny revisited: more cyclostomes, elasmobranchs, reptiles, and a brittle star. Mo Phylogenet Evol. 2007;43:1005-22.

102. Heimberg AM, Coper-Sal-lari R, Sémon M, Donoghue PCJ, Peterson KJ. microRNAs reveal the interrelationships of hagfish, lampreys, and gnathostomes and the nature of the ancestral vertebrate. Proc Natl Acad Sci U S A. 2010;107:19379-83.

103. Kuraku S, Ota KG, Kuratani S. Jawless fishes (Cyclostomata) In: Hedges SB, Kumar S, editors. The Timetree of Life. Oxford: Oxford University Press; 2009. p. 317-9.

104. Oisi Y, Ota KG, Fujimoto S, Kuratani S. Craniofacial development of hagfishes and the evolution of vertebrates. Nature. 2013;493:175-80.

105. Oisi Y, Ota KG, Fujimoto S, Kuratani S. Development of the chondrocranium in hagfishes, with special reference to the early evolution of vertebrates. Zool Sci. 2013;30:944-61.

106. Ota KG, Kuratani S. History of scientific endeavours towards the hagfish embryology. Zool Sci. 2006;23:403-18.

107. Kuratani S. Evolution of the vertebrate jaw from developmental perspectives. Evol Dev. 2012;14:76-92.

108. Kuratani S, Ahlberg PE. Evolution of the vertebrate neurocranium: problems of the premandibular domain and trabecula. Zool Lett. 2018;4:1.

109. Jeffery WR, Swalla BJ. Evolution of alternate modes of development in ascidians. BioEssays. 1992;14:219-26.
110. Northcutt RG, Gans C. The genesis of neural crest and epidermal placodes: a reinterpretation of vertebrate origins. Q Rev Biol. 1983;58:1-28.

111. Jeffery WR. Ascidian neural crest-like cells: phylogenetic distribution, relationship to larval complexity, and pigment cell fate. J Exp Zool (Mol Dev Evol). 2006;306B:470-80.

112. Jeffery WR. Chordate ancestry of the neural crest: new insights from ascidians. Semin Cell Dev Biol. 2007;18:481-91.

113. Jeffery WR, Strickler AG, Yamamoto Y. Migratory neural crest-like cells form body pigmentation in a urochordate embryo. Nature. 2004;431:696-9.

114. Jeffery WR, Chiba T, Krajka FR, Deyts C, Satoh N, Joly JS. Trunk lateral cells are neural crest-like cells in the ascidian Ciona intestinalis: insights into the ancestry and evolution of the neural crest. Dev Biol. 2008;324:152-60.

115. Sauka-Spengler T, Meulemans D, Jones M, Bronner-Fraser M. Ancient evolutionary origin of the neural crest gene regulatory network. Dev Cell. 2007;13:405-20.

116. Meulemans D, Bronner-Fraser M. Insights from amphioxus into the evolution of vertebrate cartilage. PlosOne. 2007;2(e787):1-9.

117. Abitua PB, Wanger E, Navarrete IA, Levine M. Identification of a rudimentary neural crest in a non-vertebrate chordate. Nature. 2012;492:104-7.

118. Stolfi A, Ryan K, Meinertzhagen IA, Christiaen L. Migratory neuronal progenitors arise from the neural plate borders in tunicates. Nature. 2015; 527:371-4.

119. Holland PWH, Holland LZ, Williams NA, Holland ND. An amphioxus homeobox gene: sequence conservation, spatial expression during development and insights into vertebrate evolution. Development. 1992; 116:653-61.

120. Holland ND, Chen J. Origin and early evolution of the vertebrates: new insights from advances in molecular biology, anatomy and palaeontology. Bioessays. 2001;23:142-51.

121. Holland LZ. Chordate roots of the vertebrate nervous system: expanding the molecular toolkit. Nat Rev Neurosci. 2009;10:736.

122. Holland LZ. Evolution of basal deuterostome nervous systems. J Exp Biol. 2015;218:637-45.

123. Holland LZ, Carvalho JE, Escriva H, Laudet V, Schubert M, Shimeld SM, Yu JK. Evolution of bilaterian central nervous systems: a single origin? EvoDevo. 2013;4:27.

124. Sugahara F, Pascual-Anaya J, Oisi Y, Kuraku S, Aota S, Adachi N, Takagi W, Hirai T, Sato N, Murakami Y, Kuratani S. Evidence from cyclostomes for complex regionalization of the ancestral vertebrate brain. Nature. 2016;531:97-100.

125. Kuratani S. Spatial distribution of postotic crest cells defines the head/trunk interface of the vertebrate body: embryological interpretation of peripheral nerve morphology and evolution of the vertebrate head. Anat Embryol. 1997;195:1-13.

126. Holland LZ, Kene M, Williams NA, Holland ND. Sequence and embryonic expression of the amphioxus engrailed gene (AmphiEn): the metameric pattern of transcription resembles that of its segment-polarity homolog in Drosophila. Development. 1997;124:1723-32.

127. Neal HV. The segmentation of the nervous system in Squalus acanthias. Bull Mus Comp Zool. 1898;31:147-294.

128. Kuratani S. Evolutionary developmental studies of cyclostomes and origin of the vertebrate neck. Dev. Growth Diff. 2008;50(1):S189-94.

129. Goodrich ES. Structure and development of vertebrates. London: Macmillan; 1930.

130. de Beer GR. The development of the vertebrate skull. London: Oxford University Press; 1937.

131. Suzuki DG, Fukumoto Y, Yoshimura M, Yamazaki Y, Kosaka J, Kuratani S, Wada H. Comparative morphology and development of extra-ocular muscles in the lamprey and gnathostomes reveal the ancestral state and developmental patterns of the vertebrate head. Zool Lett. 2016;2:10.

132. Wiedersheim R. Vergleichende Anatomie der Wirbeltiere: Für Studierende bearb. 7te Auflage. G: Fischer; 1909.

133. Gaupp E. Die Entwicklung des Kopfskelettes. In: Handbuch der vergleichenden und experimentalen Entwickelungsgeschichte der Wirbeltiere, Bd. 3, Theil. 2; 1906.

134. Jollie MT. Segmentation of the vertebrate head. Am Zool. 1977;17:323-33.

135. Kuratani S, Oisi Y, Ota KG. Evolution of the vertebrate cranium: viewed from the hagfish developmental studies. Zool Sci. 2016;33:229-38.

136. Hirasawa T, Kuratani S. Evolution of the vertebrate skeleton - morphology, embryology and development. Zool Lett. 2015;1:2

137. Ota GK, Kuratani S. 'Evolutionary Origin of Bone and Cartilage in Vertebrates. In: Pourquié O, editor. Cold Spring Harbor Monograph Series 53, The Skeletal System: Cold Spring Harbor Laboratory Press; 2009. p. 1-18. 
138. Hirasawa T, Oisi Y, Kuratani S. Palaeospondylus as a primitive hagfish. Zool Lett. 2016;2:20

139. Willey A. Amphioxus and the ancestry of the Vertebrates. New York: Macmillan; 1894

140. Urata M, Yamaguchi N, Henmi Y, Yasui K. Larval development of the oriental lancelet, Branchiostoma belcheri in laboratory mass culture. Zool Sci. 2007: 24:787-97.

141. Kaji T, Aizawa S, Uemura M, Yasui K. Establishement of left-right asymmetric innervation in the lancelet oral region. J Comp Neurol. 2001;435:394-405.

142. Fritzsch B, Northcutt G. Cranial and spinal nerve organization in Amphioxus and lampreys: evidence for an ancestral craniate pattern. Act Anat. 1993;148: 96-109.

143. Kaji T, Reimer JD, Morov AR, Kuratani S, Yasui K. Amphioxus mouth after dorso-ventral inversion. Zool Lett. 2016;2:2.

144. Froriep A. Über ein Ganglion des Hypoglossus und Wirbelanlagen in der Occipitalregion. Arch Anat Physiol. 1882;1882:279-302.

145. Kuratani S, Tanaka S, Ishikawa Y, Zukeran C. Early development of the hypoglossal nerve in the chick embryo as observed by the whole-mount staining method. Am J Anat. 1988;182:155-68.

146. Matsuoka T, Ahlberg PE, Kessaris N, lannarelli P, Dennehy U, Richardson WD, McMahon AP, Koentges G. Neural crest origins of the neck and shoulder. Nature. 2005:436(7049):347-55

147. Oisi Y, Fujimoto S, Ota KG, Kuratani S. On the peculiar morphology and development of the hypoglossal, glossopharyngeal and vagus nerves and hypobranchial muscles in the hagfish. Zool Lett. 2015;1:6.

148. Tada M, Kuratani S. Evolutional and developmental understanding of the spinal accessory nerve. Zool Lett. 2015;1:4.

149. Basic Structure JE. Evolution of Vertebrates, vol. 2. New York: Academic Press; 1980.

150. Oken L. Über die Bedeutung der Schädelknochen. Göbhardt; 1807.

151. Goethe JW. Schädelgrüst aus sechs Wirbelknochen aufgebaut. Zur Morphologie, Band 2, Heft 2; 1824.

152. Vicq $D^{\prime}$, Azyr F. Observations anatomiques sur trois Singes appelés le Mandrill, le Callitriche et le Macaque; suivies de qu elques Réflexions sur plusieurs points d'Anatomie comparée: Mém de Mathém.et Physique de l'Acad Roy d Sciences; 1780.

153. Balfour FM. The development of the elasmobranchial fishes. J Anat Physiol. 1878;11:405-706

154. van Wijhe JW. Über die Mesodermsegmente und die Entwicklung der Nerven des Selachierkopfes. Ver. Akad. Wiss, Amsterdam, Groningen; 1882;p. $1-50$.

155. Kuratani S, Adachi N. What are head cavities? - history of studies on the vertebrate head segmentation. Zool Sci. 2016;33:213-28.

156. Adachi N, Kuratani S. Development of head and trunk mesoderm in a dogfish, Scyliorhinus torazame. I. Embryology and morphology of the head cavities and related structures. Evol Dev. 2012;14:234-56.

157. Adachi N, Takechi M, Hirai T, Kuratani S. Development of the head and trunk mesoderm in the dogfish, Scyliorhinus torazame. II. Comparison of gene expressions between the head mesoderm and somites with reference to the origin of the vertebrate head. Evol Dev. 2012;14:257-76.

158. Onai T, Aramaki T, Inomata H, Hirai T, Kuratani S. Ancestral mesodermal reorganization and evolution of the vertebrate head. Zool Lett. 2015;1:29.

159. Onai T, Aramaki T, Inomata H, Hirai T, Kuratani S. On the origin of vertebrate somites. Zool Lett. 2015;1:33.

160. Masterman AT. On the theory of archimeric segmentation and its bearing upon the phyletic classification of the chordata. Proc Roy Acad Sci Edinburgh. 1898:22:270-310.

161. Zur Metamerie RA. Metamerism und Metamerisation bei Wirbeltiere. Zool Anz. 1963:170:489-502.

162. Remane A. The enterocoelic origin of the coelom. In: Dougherty EC, editor. The lower Metazoa; 1963b. p. 78-90.

163. Starck D. Vergleichende Anatomie der Wirbeltiere auf evolutionsbiologischer Grundlage. 1. Theoretische Grundlagen; Stammesgeschichte und Systematik unter Berücksichtung der diederen Chordata: Springer; 1978.

164. Wedin, B. The Anterior Mesoblast in Some Lower Vertebrates - A Comparative Study of the Ontogenetic Development of the Anterior Mesoblast in Petromyzon, Etmopterus, Torpedo, et al. Lund: Hakan Ohlsson Boktryckeri. 1949.

Ready to submit your research? Choose BMC and benefit from:

- fast, convenient online submission

- thorough peer review by experienced researchers in your field

- rapid publication on acceptance

- support for research data, including large and complex data types

- gold Open Access which fosters wider collaboration and increased citations

- maximum visibility for your research: over $100 \mathrm{M}$ website views per year

At $\mathrm{BMC}$, research is always in progress.

Learn more biomedcentral.com/submissions 